Portland State University

PDXScholar

Dissertations and Theses

Dissertations and Theses

1974

\title{
A follow-up study of community organization concentrators
}

Hedy-Jo Huss Powell

Portland State University

Follow this and additional works at: https://pdxscholar.library.pdx.edu/open_access_etds

Part of the Public Administration Commons, Social Welfare Commons, and the Social Work Commons Let us know how access to this document benefits you.

\section{Recommended Citation}

Powell, Hedy-Jo Huss, "A follow-up study of community organization concentrators" (1974). Dissertations and Theses. Paper 1765.

https://doi.org/10.15760/etd.1764

This Thesis is brought to you for free and open access. It has been accepted for inclusion in Dissertations and Theses by an authorized administrator of PDXScholar. Please contact us if we can make this document more accessible: pdxscholar@pdx.edu. 
A FOLLOW-UF STUDY OF COMMUNITY OROANIZATION CONCENTRATCFS

by

HEDY - JO HUSS POWELL

\section{A report submitted in partial fulfillment of the requirements for the degree of}

MASTER CF

SOCIAL WORK

\section{Fortland State University \\ 1974}

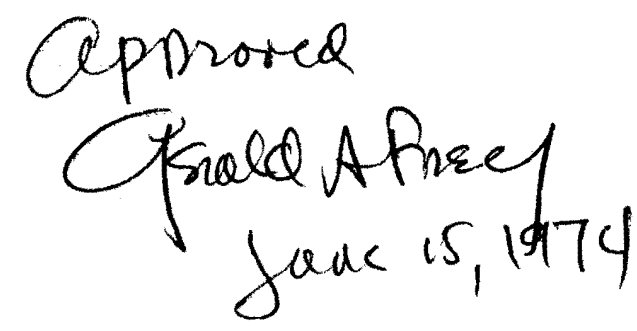


ABSTRACT

This follow-up study of 1970-73 graduates of the Portland State University School of Social Work was aimed at identifying the community organization and social welfare planning skills that M.S.W.s are using in their current practice. The study sought information from graduates that could be useful in evaluating the current Social Welfare Planning concentration and planning future curriculum.

Two groups of graduates were surveyed utilizing a mailed questionnaire. The first group consisted of the universal sample of former students identified as community organization concentrators; the comparison group was a sample of graduates who had majored in direct services.

The study explored and compared the educational backgrounds of the two groups and their employment histories following graduation. More importantly, it sought the opinions of former students on the usefulness or relevancy of specific community organization and planning skills in their actual practice.

At the outset of the study, it was assumed that graduates who had concentrated in community organization would consistently rate community organization/planning skills higher than graduates who had majored in direct services. Overall, the results of the study substantiated that assumption. However, the agency setting of the practitioner appeared to be a more important determinant of the types of skills he found relevant than his anea of specialization in graduate 
school.

Thus, community organization concentrators who were in organizing or planning positions at the time of the survey rated the associated skills as having much greater utility in their practice than did direct service concentrators who held direct service positions. Further, direct service concentrators who were also in administrative or planning positions rated the skills higher than did their counterparts in direct service positions.

It was also found that community organization concentrators were more conservative than direct service majors in crediting the School of Social Work with having contributed significantly to their attainment of community organization/planning skills. 
TABLE OF CONTENTS

Chapter

Page

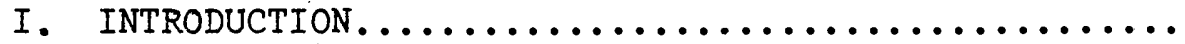

Historical Framework and Definitions...........

Evolution of the Social Welfare Planning

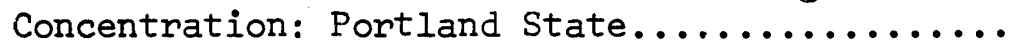

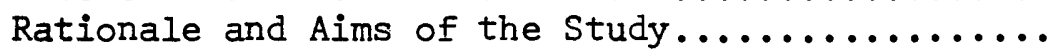

Cliapter

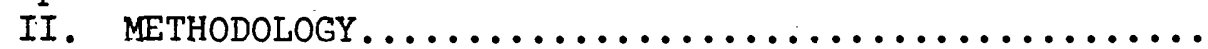

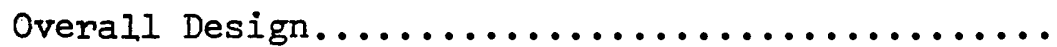

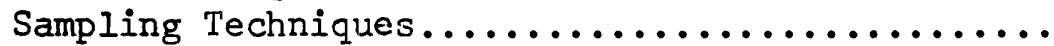

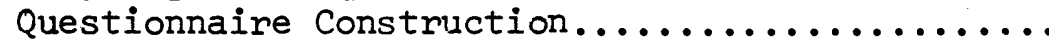

Chapter

III. FINDINGS AND CONCLUSIONS.................. 19

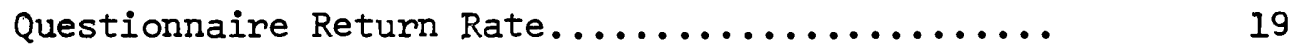

Self-identification of Concentration............

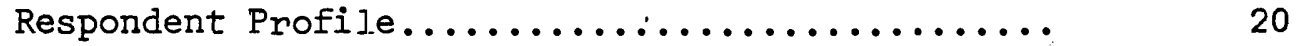

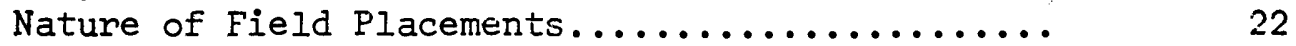

Employment Histories Following Graduation........ 25

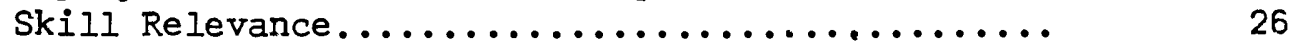

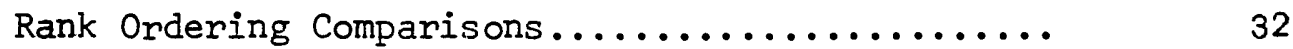

Assessment of the School's Contribution......... 37

Summary ............................ 40

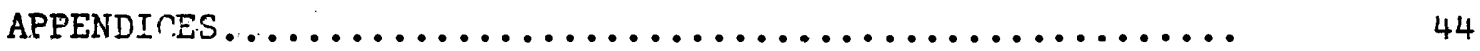

A. Cover Letter and Questionnaire.............. 44

B. Lowy's Student Questionnaire................ 52

C. Action Concepts......................... 55

D. Friedlander's Community Organization Skills... 60

E. Columbia University Skiils Outline.......... 63

F. Minutes of Planners "Brainstorming" Session.. 70

G. Tables of Group Means and the Variance Around the Means on Skills.............. 77

H. Table of Group Means on Skill Items Based on Respondent's Type of Practice.......... 80

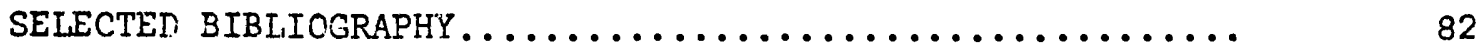


CHAPTER I

INTRODUCTION

Historical Framework and Definitions

Over the past fifty years, social work educators and practitioners have been grappling with developing concepts and a firm methodology for the field of community organization and planning. Initially, community organization was regarded as a facet of urban sociology. Later, it became associated with social work, but ancillary to direct services. Until the late 1930s, community organization and planning remained in the province of community health and welfare councils. It was broadly defined as "practice in community settings involving organization and planning functions." ${ }^{\prime}$

The Lane Report, presented at the 1939 National Conference of Social Work, unged that community organization be recognized as a legitimate method of social work practice and that professional schools provide this specialization in their curriculum designs. ${ }^{2}$

However, it was not until 1962 that community organization was fomally recognized as a method or specialty area in accredited schools of social work. By the terms of the 1962 Curriculum Policy

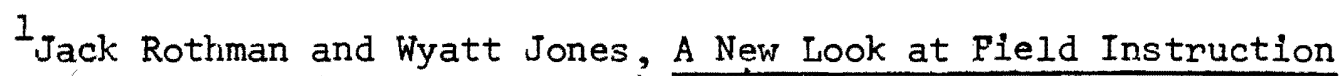
(New York: Association Press, 1971), Pp. 1-10.

${ }^{2}$ Amold Gurin, Community Organization Curriculum in Graduate Social Work Education (New York: Council on Social Work Education, 1970), FP. $4-5$. 
Statement of the Council on Social Work Education (CSWE), community organization was to be considered "on a level of parity with casework and group work as an area of concentration." 1

A number of graduate schools had previously instituted such a two-year concentration and many more have inaugurated programs over the past decade. Rothman and Jones reported that in 1967 , fortythree of the seventy accredited schools of social work had a community organization curriculum and that over eight percent of their combined enrollments were community organization concentrators. 2

Both the number and percentage of community organization concentrators in schools of social work across the country increased each year from 1960 to 1969. Table 1 illustrates the dramatic growth of the community organization concentration in recent years.

The statistics on the growth of the community organization concentration may be interpreted as reflecting changed student attitudes and educational objectives. When community organization first became available as an option, students tended to shy away from that concentration, usually because they felt its theoretical base was weak or that they would not be able to locate employment in the field. ${ }^{3}$

I Ibid, p. xviii.

2 Rothman and Jones, A New Look, p. 10.

3 Werner Boehm, ge. ed., Council on Social Work Education Curriculum Study, 12 vols. (New York: Council on Social Work Education, 1959), vol. 4: The Community Organization Method in Social Work Education, by Harry L. Lurie, ed., p. 7 . 
TABLE 1

FULI-TIME STUDENT ENROLLMENT IN MASTER'S DEGREE PROGRAM

AND ENROLLMENT IN COMMUNITY ORGANIZATION

CONCENTRATION, 1960-1969

\begin{tabular}{|c|c|c|c|c|c|}
\hline Year & $\begin{array}{l}\quad \text { Total } \\
\text { Full-time } \\
\text { Enrollment }\end{array}$ & $\begin{array}{c}\text { Enrollment } \\
\text { in } \\
\text { c. } 0 . \\
\end{array}$ & $\begin{array}{l}\text { Percentage of } \\
\text { all students } \\
\text { in } c .0 \text {. }\end{array}$ & \multicolumn{2}{|c|}{$\begin{array}{l}\% \text { Increase Over } \\
\text { Previous Year In }\end{array}$} \\
\hline 1960 & 5,461 & 85 & 1.5 & -- & -- \\
\hline $\begin{array}{l}1961 \\
1962 \\
1963\end{array}$ & $\begin{array}{l}5,864 \\
6,490 \\
7,074\end{array}$ & $\begin{array}{l}100 \\
141 \\
201\end{array}$ & $\begin{array}{l}1.7 \\
2.2 \\
2.9\end{array}$ & $\begin{array}{l}7.38 \\
7.88 \\
9.00\end{array}$ & $\begin{array}{l}17.65 \\
41.00 \\
42.55\end{array}$ \\
\hline 1964 & 7,925 & 297 & 3.8 & 12.03 & 47.76 \\
\hline 1965 & 8,989 & 442 & 4.9 & 13.43 & 48.82 \\
\hline 1966 & 10,131 & 789 & 7.8 & 12.70 & 78.51 \\
\hline 1967 & 10,961 & 897 & 8.2 & 8.19 & 13.69 \\
\hline 1968 & 11,700 & 1,017 & 8.7 & 6.74 & 13.38 \\
\hline 1969 & 12,551 & 1,125 & 9.0 & 7.27 & 10.62 \\
\hline
\end{tabular}

SOURCE: Statistics on Social Work Education, 1960 through 1969, in Gurin, Co Method, P. 195.

There is also a trend toward expanding and changing the design of the community organization curriculum in many. graduate schools of social work. Social Welfare Planning concentrations, providing a curriculum focused on planning, management and organizing skills, are gaining predominance. The nature of social welfare planning as a practice area is evolving. Consequently, formal definitions are often imprecise and arbitrary.

Kahn, preferring to operationalize the elements of sccial welfare planning rather than state a formal definition, suggests that such planning involves (1) conducting preliminary explorations, (2) defining planning tasks, (3) formulating policy, (4) programming 
and, (5) implementing reporting, evaluation and feedback systems. ${ }^{1}$ In this report, community organization shall refer to the more comprehensive social welfare planning concentration model. Thus, "the emphasis in social welfare planning is upon such social work practice areas as inter-organization administration, legislative action and social policy formation." ${ }^{2}$

\section{Evolution of the Social Welfare Planning Concentration:} Portland State University

The Portland State University School of Social Work first introduced a community organization concentration during the 19691970 academic year. That first program, called the Community Work Program, was extremely limited in scope and geared toward meeting the needs of second year students who had been involved in community work their first year. During the 1969-70 school year, no effort was made to place interested first year students in community organization/planning field placements.

The following year, an introductory community organization survey course was made a requirement for all first year students. The rationale for this change was to expose all students to this field and, thereby, help them to select their area of specialization.

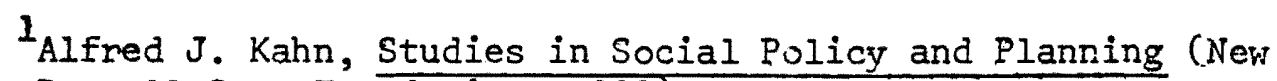
York: Russell Sage Foundation, 1969), p. I.

2 Portland State University School of Social Work, "The Social Welfare Flanning Concentration," Draft of chapter for the 1974 Reaccreditation Report (Portland, Ore.: 1973), p. 1. 
In addition to the second year methods sequence which became operational the preceding year, a community organization research course was also made available.

The community organization "track" continued to expand in the 1971-72 school year. A number of first year students inclined toward community organization/planning were placed in these field settings for the first time. No community organization methods courses were set up for first year students choosing that area of concentration; however, several community organization electives were offered.

Roughly the same curriculum continued into 1972-73. Because all first year students were required to enroll in a full-year "core course", the requirement of taking an introductory community organization course was dropped. A two-year community organization methods sequence was added for first year students beginning winter term of 1973. The variety of community organization/planning electives was also increased.

The 1973-74 community organization curriculum closely paralleled the previous year's format. However, a major policy change was adopted by the faculty in the spring of 1973. The School of Social Work decided to revamp and retitle the community organization option. Thus, the recently created Social Welfare Planning Option is, at this writing, still evolving. ${ }^{1}$ An outline of the development of the Social Welfare Planning Option is shown in Table 2.

${ }^{1_{\text {Ibid. }}}$ 
TABLE 2

THE EVOLUTION OF THE SOCIAL WELFARE PLANNING CONCENTRATION

$1969-70$

Community Work

Program Sequence: second year option courses

$$
1970-71
$$

Introductory Course in Community Organization required of all first year students

Previous methods courses revised for second year students

\section{1-72}

Introductory

Course continues as a requirement

Community Organization and Plan-

ning field place-

ments open for

first year students

Second year specialization continues

Support courses added to curriculum
$1972-73$

Introductory

Course dropped

in favor of

"Core" course

First year

practice

courses added

leading to

a full two

year speciali-

zation

Support courses

continued
1973-74

\section{PLANNING FOR}

PROPOSED

MAJOR IN

SOCIAL WELFARE

PLANNING 
The School of Social Work decision to establish two concentrations, one in direct services and one in social welfare planning, signaled a committment on the part of the school to provide more complete and adequate programs in line with the educational and career goals of all students. Thus "the aim of the social welfare planning concentration is to assure that social work will continue to train and develop leadership in the development of social welfare programs." 1 Among the over two hundred graduates of the school since the community organization/planning option has been available, thintyfour have been classified as community organization concentrators. As the program has expanded, the number of students electing to concentrate in community organization/planning has increased. Fourteen, or over $15 \%$ of the 1973 graduating class, were community organization concentrators, a figure higher than the 1969 national percentage.

It would appear that the conditions for the development of such a specialized curriculum component, (1) the need for such specialized education, (2) the existence of a body of knowledge applicable to the spesialization, (3) opportunities for professional practice in identifiable settings and, (4) adequate numbers of people desirous of avalling themselves of such professional preparation ${ }^{2}$ are present at the School of Social Work.

${ }^{1}$ Ibid., p. 5

'Lurie, Community Organization Method, p. 231. 
Rationale and Aims of the Follow-Up Study

Owing to the small numbers of students who have concentrated in the community organization concentration at the School of Social Work, there has been the opportunity for individualized programming as well as a close relationship between faculty and students in this area of specialization. "Students have made major inputs into the structure, objectives and nature of the program both formally and informally. Thus, to a large extent, the concentration as it presently exists reflects the direct influence of students." 1

Evaluation of the community organization concentration has, to date, been sketchy and weakly documented. Assessment of the program and identification of areas which need improvement has been largely. informal and impressionistic.

The community organization has evolved in a context of (1) a total curriculum which is oriented toward generic or direct services training for first year students, (2) few faculty with a background in community organization and planning, (3) limited resources and, (4) no systematic effort to recruit and select students whose career goals are in the direction of community organization/planning. ${ }^{2}$

Future curriculum design for the Social Welfare Planning concentration should, it is felt, proceed from a more comprehensive

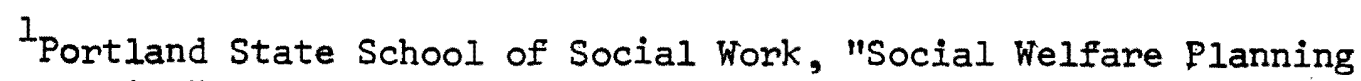
Concentration", p. 15.

${ }^{2}$ Gerald A. Frey, Memorandum on the School of Social Work Social Welfare Planning Option, 22 May 1973. (Mimeographed.) 
evaluation of the Social Welfare Planning "track" as it has developed over the past four years. The present study was undertaken to gather "hard" data on how former students viewed their training in community organization/planning areas and to get their input on the types of community organization/planning skills they are called upon to demonstrate in their actual practice. 
CHAPTER II

METHODOLOGY

Overall Design

The original design of the study was to consist of three parts: (1) a questionnaire survey of community organization concentrators who graduated from the School of Social Work from 1970-73, (2) a comparison survey of direct service majors, using an identical questionnaire and, (3) a series of in-depth interviews with community organization concentrators employed in the Portland metropolitan area. Owing to time limitations, personal interviews were not conducted. However, in the course of designing and administering the questionnaire, a number of community organization concentrators were informally interviewed. Some of the ideas and suggestions provided by those persons were incorporated in the questionnaire. A survey utilizing mailed questionnaires was selected as the most efficient method of data collection. Since the central focus of the study was on determining the relevance of community organization/planning skills to the kinds of practice graduates have been engaged in, the same questionnaire was administered to community organization concentrators and direct service majors alike.

In October, 1973, an initial draft of the questionnaire was pra-tested on three second year community organization concentrators and two M.S.W.S who have had considerable experience in the field of 
social welfare planning. The suggestions made by that group resulted in revisions in the cover letter, several questions and instructions.

In November, 1973, questionnaires were sent to thirty-four graduates designated as community organization concentrators and to an equal number of former students who had majored in direct services. The addresses of the graduates sampled were obtained from the School of Social Work card file on graduates and from other graduates and faculty members who had knowledge of their current addresses.

Analysis of the returned questionnaires began in January, 1974.

\section{Sampling Techniques}

The study used two sample groups. The first sample group, designated as community organization concentrators, were all of the graduates of the School of Social Work who had specialized, to some degree, in the community organization "track" since its inception in 1969-70. Identification of community organization concentrators was made largely by the faculty coordinator for this specialization. A total of thirty-four former students comprised the community organization concentrator sample.

The majority of the community onganization concentrators had had at least one year of field work in a community organization or social welfare planning setting and had taken accompanying methods courses. Others, who had chosen to "mix" areas of specialization, had taken at least several community organization practice and/or elective courses.

The second, comparison, group consisted of thirty-four graduates who had not concentrated in community organization/planning. Members 
of this group were selected by means of a random sampling technique. Since the universe of community organization concentrators totaled thirty-four, or approximately one in six of the 219 graduates of the 1970-73 classes, the name of every sixth direct service graduate of those years was drawn from an alphabetized list of all graduates of the School of Social Work.

The distribution of subjects sampled by thein year of graduation is shown in Table 3.

TABLE 3

DISTRIBUTION OF SUBJECTS BY YEAR OF GRADUATION

Year of Graduation

1970

1971

1972

1973
Community Organization Concentrators

4

7

9

14
Direct Service

Concentrators

7

7

7

13

Totals $34 \quad 34$

Questionnaire Construction

The questionnaire contained fifty-eight items, mostly of the fixed-alternative type. Closed, on fixed-alternative items were chosen because they limit the respondents' answers to specific alternatives and thus, "produce greater uniformity among respondents along the specific dimensions selected for study." ${ }^{1}$

Bernard S. Phillips, Social Research: Strategy and Tactics (New York: Macmillan Co., 1966), P. 117. 
The questionnaire was divided into five sections: Biographical and Background Information, Educational Experiences, Employment Information, Relationship of Skills to Job Requirements and Assessment of the School's Contribution to Skill Attainment. In order to elicit more information about community organization/planning field placements and curriculum, community organization respondents were sent a brief sixth section pertaining to these areas. (A copy of the cover letter and questionnaire are located in Appendix A.)

The general format of the questionnaire and accompanying cover letter was modeled somewhat after ones used in a recent, large-scale evaluation of graduate social work education. I (See Appendix B for selected portions of that instrument.)

The first three sections of the questionnaire sought information on the respondent's undergraduate major, types of employment prior to enrollment in the master's program, types of field placements and nature of course work in community organization/planning.

The fourth section was a list of thirty-five skills and areas of knowledge often associated with community organization and social welfare planning practice. In this section, respondents were asked to rate, or measure, each item singly in terms of its relevance to the jobs they have held since receiving their M.S.W. degree. They were instructed to circle the number on a six-point scale $(0=$ no relevance or utility to $5=$ extremely high relevance) that best described the relevance of the skill to their job tasks.

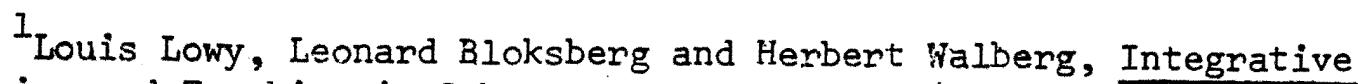
Learning and Teaching in Schools of Social Work (New York: Association Press, 1371), PP. 263-270. 
By utilizing single-item measurement procedures, each of the thirty-five items could be measured separately. One of the strongest points for using this procedure is that it allows a wide range of concepts to be measured in a like manner. Its greatest disadvantage is that "a given item may mean different things to different respondents, or one grouping of respondents and something else to another. One person's notion of what is "indispensable" may be another's notion of "moderately important". ${ }^{1}$

The list of thirty-five community organization/planning skills and areas of knowledge was derived from a varlety of sources: (1) a review of the literature on community organization/planning practice and graduate social work education, (2) outlines, topical descriptions and printed materials used in community organization/ planning courses offered by the School of Social Work and other university departments and, (3) discussions with community organization concentrators and teaching staff. (The reader may refer to the Bibliography).

The process by which items were selected began with a collection of descriptions of community organization/planning skills from a spectrum of sources. The items were then categorized in a number of ways, eliminating duplicates. The final list was felt to contain the most relevant and characteristic skills of community organization/ planning practice.

Within the confines of this report, it would not be feasible to discuss fully all the sources of skill items. Therefore, only those

IPhillips, Social Research, p. 209. 
sources which offered a major contribution to the construction of the questionnaire shall be highlighted.

The search through the literature began with the writings of Rothman, Mornis and Binstock and Ross. ${ }^{I}$ The models of community organization/planning practice developed by these leaders have become regarded as classics in the field.

Also helpful in the construction of the skills section was a master's thesis submitted to the School of Social Work in 1965. That piece of research compiled lists of "action concepts" for each of the three social work concentrations--casework, group work and community organization.

The community organization list contained 139 "action concepts" which had been isolated from articles in the following social welfare periodicals:

The Social Worker

Social Service Review Child Welfare

The Group

Jewish Social Service Quarterly

Journal of Orthopsychiatry

Proceedings of the National Conference of Social Workers Smith College Studies in Social Work

Social Work Year Book ${ }^{2}$

${ }^{l}$ Robert Morris and Robert Binstock, Feasible Planning for Social Change (New York: Columbia University Press, 1966); Murray G. Ross, Community Organization: Theory, Principles and Practice (New York: Harper \& Brothers, 1955); and Jack Rothman, "Three Models of Community Organization," in Strategies of Community Organization, ed. Fred Cox et al. (Itasca, III.: Peacock Publishers, 1970), pp. 20-37.

${ }^{2}$ Richard DeCristoforo et al., "Development of a Tool to Measure Applicability of the General Systems Theory to Generic Social Work" (M.S.W. thesis, Portland State University School of Social Work, 1965), p. 33 . 
The complete list of skills arrived at by that study is in Appendix $C$. The limitations on the utility of those "action concepts" for this study were that many were generic and, secondly, a number of new concepts and skills have been introduced since that research was conducted.

The Council on Soclal Work Education (CSWE) has sponsored several monumental social work curriculum studies, the reports of which provided a wealth of material for the construction of the present questionnaire. The first study, conducted in the late 1950s, produced one volume of reports and recommendations for community organization curriculum in graduate schools of social work. The classification of community organization skills featured in that volume was originally developed by Walter A. Friedlander in $1958 .^{1}$ This scheme arranges community organization/planning skills under the headings of Facilitative Processes, Educational Methods, Research, Social Action and Reform, Consultation, Fund Raising, Publicity and Public Relations and Negotiation. (A chart of this scheme is in Appendix D.)

of greater import were the recent publications of a three-year comprehensive study of the community organization curriculum in graduate social work education also sponsored by CSWE. The central volume resulting from that project, Community Organization in Graduate Social Work Education: Report and Recommendations, covered a range of community organization/planning skills from which certain items were isolated for the questionnaire. ${ }^{2}$

${ }^{1}$ Lurie, ed., Community Organization Method in Social Work Education, p. 97

${ }^{2}$ Gurin, pp. 1-190 passim. 
A companion volume on the application of practice skills in community organization/planning field settings also discussed practitioner tasks and categories of practice settings. Five types of practice settings were identified: (1) urban neighborhood; communitybased, (2) rural, (3) citizens interest groups, (4) social action and, (5) other non-geographic areas of interest. ${ }^{1}$ Practice skills were viewed from the perspectives of working with client groups or with staff in these settings.

Another resource that furnished many useful constructs to the design of the questionnaire was a "hand-out" originally prepared by the Columbia University School of Social Work several years ago. It is an outline of community organization/planning skills arranged under the headings of Relationship, Organizational or Group Skills, Analytic, Strategic or Political and Administrative. ${ }^{2}$ (The complete outline is contained in Appendix E.)

Interestingly, shortly after the questionnaires were sent, there was an opportunity to compare how closely the skill items would correspond to the views of planners practicing in the community. A group of planners and program administrators responded to an invitation by the Social Welfare Planning Curriculum Committee to participate in a "brainstoming" session on community organization/planning skills in November, 1973. Almost every skill cited by that group as important

${ }^{1}$ Rothman and Jones, A New Look, pp: 17-18.

${ }^{2}$ Columbia University School of Social Work, "Skills of a Community Organizer," (New York: Columbia University School of Social Work, n.d.). (Mimeographed.) 
for planning practitioners had been included in the questionnaire. (Minutes of that meeting are located in Appendix F.)

The final section of the questionnaire involved no new items. Rather, Section V. consisted solely of a set of instructions. Respondents were directed to review the list of community organization/ planning skills and circle the numbers of the items that they felt the School of Social Work helped them gain expertise in. Thus, this section sought information on how respondents viewed their graduate training in the various skill areas. 


\section{CHAPTER III}

\section{FINDINGS AND CONCLUSIONS}

\section{Questionnaire Return Rate}

The reliability of survey data rests in large part upon the number of questionnaires returned. The higher the return rate, the greater the probability that the results of the research are generalizable to the large populations from which the samples were drawn. of course, the probability always remains that those who failed to return the questionnaire differ in significant and unknown ways from those who did respond.

of the questionnaires sent to the thirty-four community organization concentrators, eighteen or roughly 53\%, were returned. The direct service group had a slightly higher rate of return--twenty out of thinty-four or $59 \%$. Ten questionnaires, half sent to community organization subjects and half to direct service subjects were undeliverable because of no forwarding addresses. An additional three questionnaires were returned too late to be included in the analysis.

\section{Self-Identification of Concentration}

The author was curicus to learn if the "pre-assigned" community organization concentrators would identify themselves as such. When asked if they had concentrated in the community organization "track", six of the eighteen respondents from this sample group repiist that 
they had not. Instead, those six respondents indicated that they had taken a "mix" of community organization and direct services courses. The practice of blending areas of specialization has not been uncormon, particulanly during the early years of the community organization "track" when the curriculum in this area was very limited.

The strongest influences on the community organization concentrators to specialize in that field were: (1) belief that community organization/planning was the most effective field of practice for social workers (28\%), (2) previous employment and life experiences (16\%) and, (3) desire to become more skillful and highly trained as an organizer or social welfare planner (11\%).

\section{Respondent Profile}

Analysis of the background information revealed that the respondent groups were similar on a number of dimensions. The distribution of respondents according to their year of graduation is shown in Table 4.

TABLE 4

DISTRIBUTION OF RESPONDENTS BY YEAR OF GRADUATION

\begin{tabular}{|c|c|c|c|c|}
\hline \multirow[b]{2}{*}{ Year } & \multicolumn{2}{|c|}{ c.o. Group } & \multicolumn{2}{|c|}{ Direct Service Group } \\
\hline & Number & $q$ & Number & $\%$ \\
\hline 1970 & 1 & 6 & 4 & 20 \\
\hline 1971 & 2 & 11 & 4 & 20 \\
\hline 1972 & 6 & 33 & 2 & 10 \\
\hline 1973 & 9 & 50 & 10 & 50 \\
\hline
\end{tabular}


The community organization group, on the average, tended to be slightly younger and had a larger percentage of males than the direct service group. Whereas the average age of the former was 31.8 (range 26 to 45 years), that of the latter was 32.9 (range 25 to 47 years).

The two groups of respondents lined up closely in terms of thein undergraduate majors. The most common undergraduate major of community organization concentrators was sociology followed by psychology; the reverse was true of the direct service group. The range of undergraduate majors is displayed in Table 5.

TABLE 5

UNDERGRADUATE MAJORS OF RESPONDENTS

\begin{tabular}{lccccc}
\hline & \multicolumn{2}{c}{ c. O. Group } & \multicolumn{2}{c}{ Direct Service Group } \\
\cline { 5 - 5 } Number & 5 & 28 & 5 & 25 \\
Sociology & 3 & 17 & 8 & 40 \\
Psychology & 2 & 11 & 1 & 5 \\
Social Work, Welfare & 2 & 11 & 1 & 5 \\
Gen. Social Sciences & -- & -- & 2 & 10 \\
English/Literature & 1 & 6 & -- & -- \\
History & 1 & 6 & -- & -- \\
Foreign Language & 3 & 17 & 3 & 15 \\
Other & & & & & \\
\hline
\end{tabular}

*rounded to nearest percent.

The majority of respondents had some type of social work related experiences before entering the School of Social Work. The average time span between completing their undergraduate education and entering graduate school was just over five years for both groups. 
In terms of amount of social work employment prior to entering the master's program, the community organization concentrators showed a range of 0 to 7 years as compared with 0 to 8 years among the direct service majors. The mean number of years of social work employment was 2.8 years for the community organization group versus 2.4 years for the direct service group.

Approximately $60 \%$ of the respondents reported having had prior experience in direct service; only one respondent, from the community organization sample, indicated having held a community organization/ planning position. Over half of each group had been involved in Peace Corps, Vista, volunteer, club and related work prior to graduate school.

\section{Nature of Field Placements}

The first and second year field placements of the respondents, categorized into eight types of agency settings by the author, are illustrated in Table 6 .

During their first year, only one-third of the community organization respondents were place in community organization/planning settings. The large number of community organization respondents who reported being in direct service practice during their first year is reflective of the School's emphasis, until 1973, on a generic first year curriculum for all students.

The most frequently reported first year field settings of community organization respondents were, in order: (1) day care/ schools/residential treatment facilities, (2) law related, e.g. juvenile court, domestic relations services, etc., and (3) community 
action.

By comparison, the most common first year field placements of the direct service graduates were: (1) law-related, (2) public welfare/Children's Services Division and, (3) medical settings.

TABLE 6

FIELD PLACEMENTS OF RESPONDENTS

\begin{tabular}{|c|c|c|c|c|c|c|c|c|}
\hline \multirow[b]{2}{*}{ Type of setting } & \multirow[b]{2}{*}{$\begin{array}{l}\text { lst } \\
\text { No. }\end{array}$} & \multicolumn{3}{|c|}{ c.o. Group } & \multicolumn{3}{|c|}{ Direct Service } & \multirow{2}{*}{$\begin{array}{c}\text { Group } \\
\begin{array}{c}\text { year } \\
\frac{q}{0}\end{array} \\
\end{array}$} \\
\hline & & $\begin{array}{r}\text { year } \\
\frac{g}{0} *\end{array}$ & $\begin{array}{l}\text { 2nd } \\
\text { No. }\end{array}$ & $\begin{array}{c}\text { year } \\
\% \\
\end{array}$ & $\begin{array}{l}\text { lst } \\
\text { No. }\end{array}$ & $\begin{array}{c}\text { year } \\
\frac{8}{0}\end{array}$ & $\begin{array}{l}\text { 2nd } \\
\text { No. }\end{array}$ & \\
\hline Planning/Legislative & -- & -- & 7 & 39 & -- & -- & -- & -- \\
\hline $\begin{array}{l}\text { Day care/Schools/ } \\
\text { Residential }\end{array}$ & 7 & 39 & 2 & 11 & 2 & 10 & 3 & 15 \\
\hline Law-related & 3 & 17 & 2 & 11 & 6 & 30 & 1 & 5 \\
\hline Medical & 2 & 11 & -- & -- & 3 & 15 & 1 & 5 \\
\hline $\begin{array}{l}\text { Mental Health/ } \\
\text { Counseling }\end{array}$ & 1 & 6 & $\cdot 2$ & 11 & 2 & 10 & 15 & 75 \\
\hline $\begin{array}{l}\text { Welfare/Children's } \\
\text { Services }\end{array}$ & 2 & 11 & -- & -- & 4 & 20 & -- & -- \\
\hline $\begin{array}{l}\text { Community Action/Projects, } \\
\text { Consumer Groups }\end{array}$ & 3 & 17 & 5 & 28 & 2 & 10 & -- & -- \\
\hline Other & -- & -- & 7 & -- & 1 & 5 & -- & -- \\
\hline
\end{tabular}

*rounded to nearest percent.

The nature of second year field work was quite different for the commurity organization group. That year, the majority of community organization respondents $(68 \%)$ were placed in either planning/legislative or community action settings. This points to the trend of concentrating in community organization in the second year.

On the other hand, direct service respondents tended to be placed primarily in mental health/counseling agencies. A few were 
placed in law-related or medical settings, as well.

As might be expected, community organization concentrators had taken many more courses of a community organization/planning nature than had direct service graduates. Several community organization respondents had taken up to seven such courses; few had taken less than three. Not one direct service respondent had taken more than two courses of this type. A break-down of the number of courses taken by respondents, either through the School of Social Work or other university departments, is shown in Tables 7 and 8 .

TABLE 7

COMMUNITY ORGANIZATION/PLANNING COURSES TAKEN THROUGH THE SCHOOL OF SOCIAL WORK

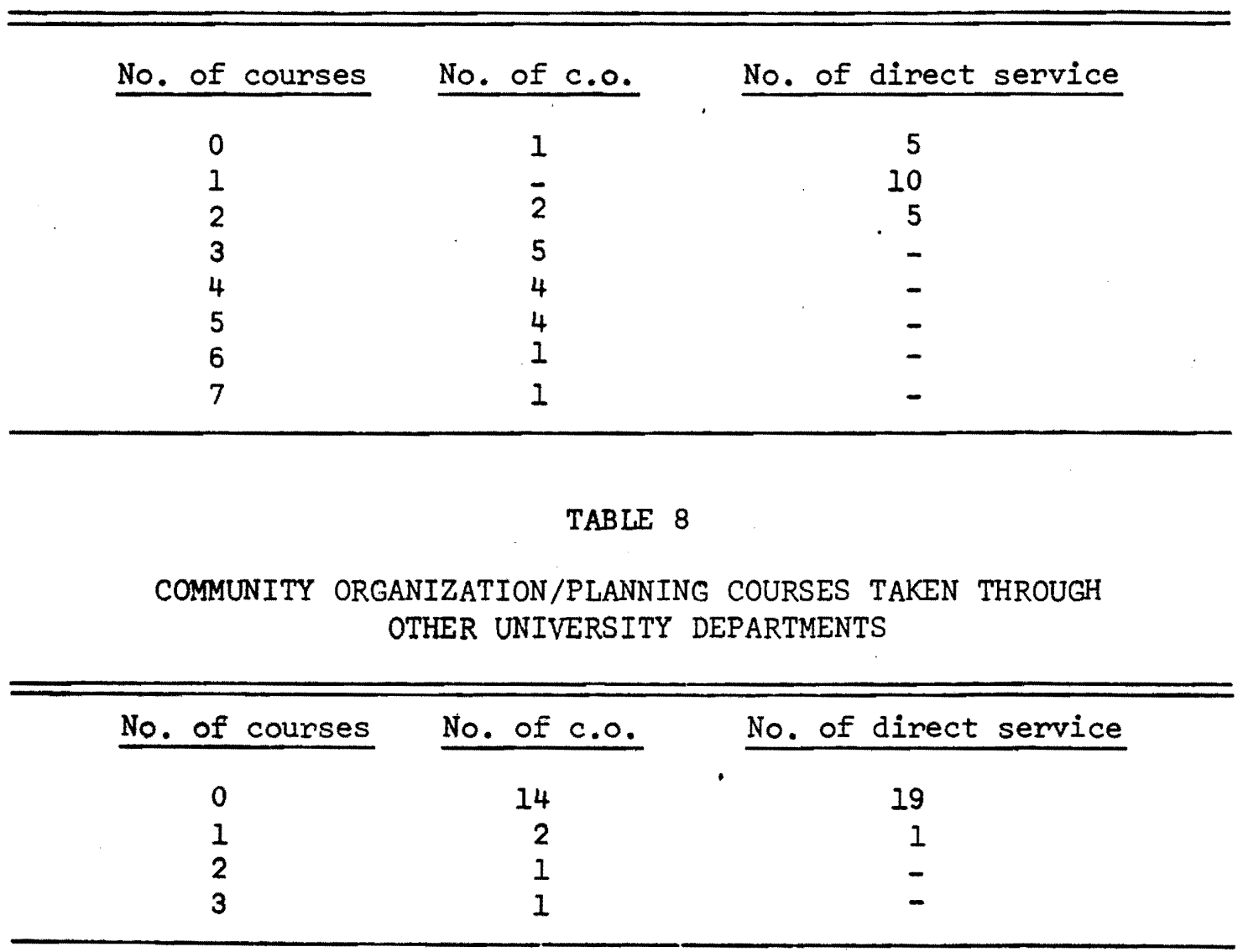


As indicated in an earlier section of this report, an introductory community organization course was a first year requirement during the 1970-71 and 1971-72 school years. This may explain why almost all direct service respondents took one community organization/planning course from the School of Social Work, whereas only one direct service respondent indicated having taken a community organization/planning course from another department.

\section{Employment Histories Following Graduation}

At the time of the survey, 16 of the 18 community organization respondents and 19 of the 20 direct service respondents were employed in a social work position. The one unemployed person from the direct service sample indicated she had deferred employment in order to be home to care for her child. The two unemployed community organization respondents had held social work positions within the past year, however.

Thirteen of the community organization respondents were, at the time of the survey, engaged in social welfare planning practice and only thiee were involved in direct services. Five of the community organization respondents were employed in states other than Oregon; however, the majority were working in the Portland metropolitan area. Further, three-quarters of this group had held only one position since graduation and only one respondent had changed jobs as many as two times.

Of the then-currently employed direct service respondents, 15 were engaged in direct service practice. The remainder were in positions, by virtue of the description given, that were community 
organization/planning in nature.

A greater proportion of the direct service group remained in Oregon following graduation. Seven were employed in the Portland area, eleven in other parts of Oregon and one out-of-state.

The annual salary levels of the community organization respondents were higher than those of the direct service group. The reported community organization concentrators salaries ranged from $\$ 9,000$ to $\$ 18,900$ per year in contrast to $\$ 5,690$ to $\$ 14,000$ for the direct service majors salaries. The average annual salary of the community organization group was $\$ 12,727$ versus $\$ 10,752$ for the direct service group. Therefore, in addition to exhibiting a higher salary range, the community organization concentrator, on the average, was earning $\$ 1,975$ more per year.

\section{Sk111 Relevancy}

This section provides an analysis of the ratings community organization and direct service concentrators gave thirty-five community organization/planning skills. The first procedure was to compute the group means, or average scores, given each skill item by the two respondent groups. The group means are helpful in locating the position on a six-point scale that respondents, as a group, tended to rate the skills. Table 9 contains the group means for each of the skill items. (Tables 10 and 11, in Appendix G, include tallies of individual scores, thus illustrating the actual variance around the means.)

One generalization was that community organization concentrators tended to rate community organization/planning skills higher than 
did direct service concentrators. The higher group means of the community organization majors indicated that these kinds of skills have had greater relevancy to their forms of social work practice than to the practice of direct service majors.

There were several exceptions to this pattern, however. On the following skills, the averaged ratings of direct service concentrators were higher than those of the community organization concentrators.

1. Develop new programs.

2. Ability to 'abstract' research reports and various studies.

3. Design and implement measures of evaluation.

4. Supervise and work closely with paraprofessionals.

5. Plan and conduct staff development and in-service training.

It is interesting that these skills, particularly the one related to abstracting reports, developing new programs and designing and carrying out program evaluation, were rated higher by direct service concentrators since they tend to be more closely associated with community organization and planning practice. The areas of supervision of paraprofessional staff and arranging staff development programs are frequently associated with practice tasks of direct service majors, however.

Overall, the group means of the two respondent groups were fairly close, but a series of $t$ tests applied to the group means did reveal statistically significant differences between the two groups on eight skill items. The differences between the group means that were significant at the .05 level are shown in Table 12 .

The results of the $t$ tests on group means are what one might expect. The community organization concentrators gave statistically higher ratings than did the direct service concentrators on skill 
TABLE 9

GROUP MEANS ON COMMUNITY ORGANIZATION/PLANNING SKILLS

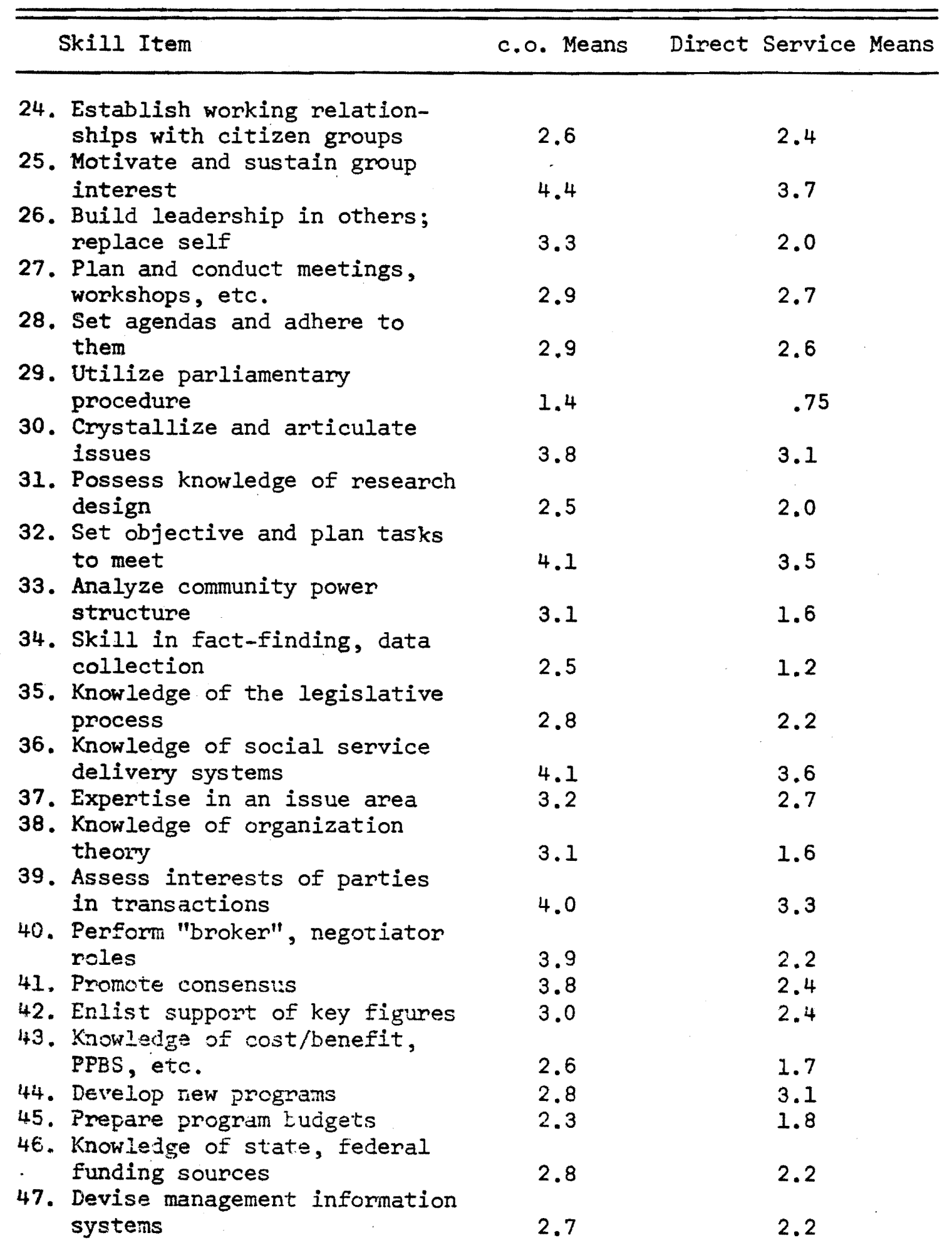


TABLE 9 (Continued)

\begin{tabular}{lll}
\hline \hline Skill Item & c.0. Means & Direct Service Means \\
\hline 48. Ability to 'abstract' reports & 2.1 & 2.1 \\
49. Serve as 'staff' to groups & 2.4 & 2.3 \\
50. Write grants and proposals & 2.3 & 1.8 \\
51. Design and implement evalua- & & \\
tion & 2.3 & 2.4 \\
52. Supervise, work with para- & 2.7 & 3.2 \\
professionals & 3.0 & 2.3 \\
53. Allot manpower efficiently & 2.5 & 1.0 \\
54. Utilize 'P.E.R.T.' techniques & & 3.1 \\
55. Prepare and argue recommenda- & 3.2 & 2.2 \\
tions & 2.6 & 2.2 \\
56. Identify 'target' groups & 2.6 & 3.4 \\
57. Utilize 'M.B.Y.' techniques & 2.9 & \\
58. Plan and conduct staff develop- & & \\
ment &
\end{tabular}

TABLE 12

SIGNIFICANT DIFFERENCES BETWEEN GROUP MEANS ON SKILL RATINGS

\begin{tabular}{|c|c|c|c|c|}
\hline \multirow[b]{2}{*}{ Skill } & \multicolumn{2}{|c|}{ Means } & \multirow{2}{*}{$\begin{array}{l}\text { Degrees } \\
\text { of } \\
\text { freedom }\end{array}$} & \multirow{2}{*}{$\begin{array}{c}t \\
\text { score }\end{array}$} \\
\hline & c.o. & Direct service & & \\
\hline \multicolumn{5}{|l|}{ Motivate and sustain } \\
\hline interest & 4.44 & 3.70 & 36 & 2.156 \\
\hline Build leadership & 3.33 & 2.05 & 30 & 2.442 \\
\hline $\begin{array}{l}\text { Analyze power structures } \\
\text { Fact-finding, data }\end{array}$ & 3.11 & 1.60 & 36 & 2.562 \\
\hline collection & 2.50 & 1.25 & 36 & 2.218 \\
\hline Knowledge of organizations & 3.11 & 1.60 & 36 & 2.932 \\
\hline Perform as 'broker' & 3.94 & 2.25 & 36 & 3.360 \\
\hline Promote consensus & 3.83 & 2.40 & 36 & 3.275 \\
\hline Utilize 'P.E.R.T.' & 2.52 & 1.00 & 30 & 2.489 \\
\hline
\end{tabular}


items most commonly attributed to social work practice in community organization and social welfare planning.

The generally higher group means of the community organization concentrators might be explained solely by their area of concentration in community organization/planning. However, this explanation does not take into account the influence a respondent's type of practice since graduation might have had on his measurements of skill relevancy. Thus, further analysis was undertaken to discover how job-determined were the ratings of community organization/planning skills.

An attempt was made to reclassify the respondents on the basis of the type of social work employment they have had since graduation. This yielded four different groupings: (1) Community organization concentrators who had been employed in conmunity organization/planning/ administration $(\mathrm{N}=14)$, (2) Direct service concentrators who were employed in community organization/planning/administration $(\mathrm{N}=4)$, (3) Direct service majors with employment in direct service positions $(\mathrm{N}=15)$ and, (4) Community onganization concentrators with employment in direct service positions $(\mathrm{N}=4)$.

It was found that the group means of community organization concentrators who were employed in community organization/planning/ administrative positions were even higher than those of the community organization sample as a whole except on one item. On the item "Utilize Parliamentary Procedures", the reclassified community organization sample had a group mean equal to that of the original community organization sample.

While still lower than the original community organization 
concentrator sample, the group means of direct service concentrators who were also in community organization/planning/administrative positions were higher on most skill items than the group means of the original direct service concentrator sample.

Thus, both community organization and direct service concentrators who were in community organization/planning/administrative positions tended to rate these skills higher than their respective sample group as a whole. The group means of the other reclassified samples provided further evidence that the respondent's type of practice is a stronger determinant of skill ratings than his area of concentration in graduate school.

Direct service concentrators who were in direct service positions following graduation had lower group means than the direct service sample as a whole. Interestingly, community organization concentrators who were employed in direct service tended not only to rate community organization/planning skills lower than the community organization respondents as a whole, but in most cases, lower than direct service concentrators in direct service. Since the reclassified community organization sample consisted of only four respondents compared with fifteen direct service respondents, the latter may have had a broader range of job tasks, and thus a greater chance of some respondents requiring community organization/planning skills.

Table 13, located in Appendix H, shows the group means of the original and the four reclassified samples on the thirty-five conmunity organization/planning skill items.

The results of these comparisons indicate that the type of 
social work respondents are engaged in is probably a more important factor in how they rate the relevancy of community organization/ planning skills than their area of specialization in graduate school.

\section{Rank Ordering Comparisons}

Another way of analyzing the data was to arrange the skill items from highest to lowest relevancy on the basis of group means. Tables 14 and 15 show the rank orderings that resulted for the community organization and direct service concentrator samples. Items with identical group means were assigned the same rank.

One of the unexpected findings was that there was strong agreement between the community organization and direct service concentrators on the skills that rated either very high or very low. On the followIng items, the community organization group means were higher; however, both groups regarded these skills as extremely relevant to their practice performance:

- Motivate and sustain group interest in a plan or goal. . Set objectives and plan tasks to them. .Possess knowledge of social service delivery systems. . Accurately assess the interests of all parties in a transaction.

. Crystallize and articulate issues. . Prepare and argue recommendations.

There is a strong possibility that both groups rated these skills higher than others because they are among the most generic and, hence, common to both types of specialization. They are also among the least technical or job-specific. Thus, it appears that the skills that ranked highest are of a different order than those that were ranked lower. 
TABLE 14

COMMINITY ORGANIZATION RANKINGS OF SKILLS BASED ON GROUP MEAN

\begin{tabular}{|c|c|c|c|}
\hline Rank & Mean & Skill Description & $\begin{array}{l}\% \text { Felt SSW } \\
\text { Contributed }\end{array}$ \\
\hline 1 & 4.4 & Motivate and sustain group interest & 56 \\
\hline \multirow{2}{*}{2} & 4.1 & Set objectives; plan tasks to achieve & 39 \\
\hline & 4.1 & Knowledge of social service delivery sys. & 50 \\
\hline 3 & 4.0 & Assess interests of parties in transactions & 44 \\
\hline 4 & 3.9 & Perform as "broker", negotiator, etc. & 39 \\
\hline \multirow{2}{*}{5} & 3.8 & Crystallize and articulate issues & 56 \\
\hline & 3.8 & Promote consensus & 50 \\
\hline 6 & 3.3 & Build leadership; replace self & 28 \\
\hline \multirow[t]{2}{*}{7} & 3.2 & Expertise in at least one issue area & 45 \\
\hline & 3.2 & Prepare and argue set of recommendations & 50 \\
\hline \multirow{2}{*}{8} & 3.1 & Analyze community power structures & 50 \\
\hline & 3.1 & Knowledge of organizational theory, analyze & 28 \\
\hline \multirow{2}{*}{9} & 3.0 & Enlist support of key figures & 17 \\
\hline & 3.0 & Organize and allot manpower resources & 6 \\
\hline \multirow{3}{*}{10} & 2.9 & Plan and conduct meetings, workshops, etc. & 17 \\
\hline & 2.9 & Set and adhere to agendas & 0 \\
\hline & 2.9 & Plan and conduct staff development & 28 \\
\hline \multirow{3}{*}{11} & 2.8 & Knowledge of legislative processes & 44 \\
\hline & 2.8 & Develop new programs & 22 \\
\hline & 2.8 & Knowledge of funding sources & 17 \\
\hline \multirow{2}{*}{12} & 2.7 & Devise management information systems & 6 \\
\hline & 2.7 & Supervise and work with paraprofessionals & 17 \\
\hline \multirow{4}{*}{13} & 2.6 & Identify target groups and strategies & 44 \\
\hline & 2.6 & Utilize management-by-objectives & 28 \\
\hline & 2.6 & Establish working relationships with groups & 45 \\
\hline & 2.6 & Knowledge of cost/benefit, PPBS, etc. & 23 \\
\hline \multirow{3}{*}{14} & 2.5 & Knowledge of research design, methodologies & 45 \\
\hline & 2.5 & Skill in fact-finding, data collection & 23 \\
\hline & 2.5 & Utilize "PERT" techniques & 23 \\
\hline 15 & 2.4 & Serve as "staff" & 23 \\
\hline
\end{tabular}


TABLE 14 (Continued)

\begin{tabular}{lclc}
\hline \hline Rank & Mean & Skill Description & $\begin{array}{c}\text { \% Felt SSW } \\
\text { Contributed* }\end{array}$ \\
\hline \multirow{2}{*}{16} & 2.3 & Prepare program budgets & 17 \\
\cline { 2 - 4 } & 2.3 & Write a grant or proposal & 28 \\
\cline { 2 - 4 } & 2.3 & Design and implement evaluation & 11 \\
\hline 17 & 2.1 & Ability to "abstract" reports, etc. & 28 \\
\hline 18 & 1.4 & Utilize Parliamentary procedures & 0 \\
\hline & & & $* N=18$
\end{tabular}


TABLE 15

DIRECT SERVICE RANKING OF SKIIIS BASED ON GROUP MEAN

\begin{tabular}{|c|c|c|c|}
\hline Rank & Mean & Skill Description & $\begin{array}{l}\text { \% Felt SSW } \\
\text { Contributed* }\end{array}$ \\
\hline 1 & 3.7 & Motivate and sustain group interest & 50 \\
\hline 2 & 3.6 & Knowledge of social service delivery sys. & 70 \\
\hline 3 & 3.5 & Set objectives-plan tasks to achieve & 40 \\
\hline 4 & 3.4 & Plan and conduct staff development & 40 \\
\hline 5 & 3.3 & Assess interests of parties in transactions & 75 \\
\hline 6 & 3.2 & Supervise and work with paraprofessionals & 55 \\
\hline \multirow{3}{*}{7} & 3.1 & Crystallize and articulate issues & 70 \\
\hline & 3.1 & Develop new programs & 30 \\
\hline & 3.1 & Prepare and argue set of recommendations & 50 \\
\hline \multirow[t]{2}{*}{8} & 2.7 & Plan and conduct meetings, workshops, etc. & 35 \\
\hline & 2.7 & Expertise in at least one issue area & 35 \\
\hline 9 & 2.6 & Set and adhere to agendas & 20 \\
\hline \multirow{4}{*}{10} & 2.4 & $\begin{array}{l}\text { Establish working relationships with } \\
\text { groups }\end{array}$ & 10 \\
\hline & 2.4 & Promote consensus & 55 \\
\hline & 2.4 & Enlist support of key figures & 10 \\
\hline & 2.4 & Design and implement evaluation & 30 \\
\hline \multirow{2}{*}{11} & 2.3 & Serve as "staff" & 25 \\
\hline & 2.3 & Organize and allot manpower resources & 10 \\
\hline \multirow{6}{*}{12} & 2.2 & Knowledge of legislative processes & 15 \\
\hline & 2.2 & Perform as "broker", negotiator, etc. & 35 \\
\hline & 2.2 & Knowledge of funding sources & 15 \\
\hline & 2.2 & Devise management information systems & 25 \\
\hline & 2.2 & Identify target groups and strategies & 35 \\
\hline & 2.2 & Utilize management-by-objectives & 10 \\
\hline 13 & 2.1 & Ability to "abstract" reports, etc. & 55 \\
\hline \multirow{2}{*}{14} & 2.0 & Build leadership; replace self & 20 \\
\hline & 2.0 & Knowledge of research design methodology & 95 \\
\hline \multirow{2}{*}{15} & 1.8 & Prepare program budgets & 10 \\
\hline & 1.8 & Write grants and proposals & 30 \\
\hline .16 & 1.7 & Knowledge of cost/benefit, PPBS, etc. & 25 \\
\hline
\end{tabular}


TABLE 15 (Continued)

\begin{tabular}{lccc}
\hline \hline Rank & Mean & Skill Description & $\begin{array}{c}\text { \& Felt SSW } \\
\text { Contributed* }\end{array}$ \\
\hline \multirow{2}{*}{17} & 1.6 & Analyze community power structures & 45 \\
\cline { 2 - 4 } & 1.6 & Knowledge of organization theory, etc. & 50 \\
\hline 18 & 1.2 & Skill in fact-finding data collection & 40 \\
\hline 19 & 1.0 & Utilize "PERT" techniques & 15 \\
\hline 20 & .75 & Utilize Parliamentary procedures & 5 \\
\hline
\end{tabular}

$*_{\mathrm{N}}=20$ 
The tendency for respondents of both groups to rank skills of a general nature higher than those of a more specific and technical nature may explain why community organization concentrators, as well as direct service majors, rated the following skills among the least relevant to their practice tasks:

. Knowledge of research design and methodologies. - Prepare program budgets. . Write grants and proposals. .Knowledge of cost/benefit, PPBS, etc. . Skill in fact-finding, data collection. .Knowledge of 'P.E.R.T.' techniques. .Skill in utilizing Parliamentary procedure.

Caution must be exercised in interpreting these kinds of comparisons because the rank orderings vere based on group means. Thus, a number of skill items were found to share a rank which tended to distort the meaning of the ordering. This would not have been the case had respondents been instructed to rank order the thirty-five skills in terms of their relevancy to practice.

\section{Assessment of the School's Contribution}

The percentages of respondents that indicated their graduate social work training contributed greatly to their attainment of the various skills are shown in Tables 14 and 15, also. In general, respondents tended to credit the School of Social Work for assisting in the mastery of skills they rated as most relevant to their practice. Overall, the community organization concentrators were more conservative in crediting the School with contributing to their expertise.

A major finding was that direct service respondents frequently cited the School of Scoial Work as having contributed to their gain 
of skill in areas they rated as having little relevance to their practice following graduation. For example, while their group mean ratings for such items as research design, knowledge of organizational theory and analysis and fact-finding and data collection were low, the percentage of direct service respondents that felt the School contributed significantly to their expertise in these areas was high.

Conversely, while the group means of the community organization concentrators were higher on these same items, the percentage of respondents that felt the School contributed to their skill mastery was appreciably lower than that of the direct service group.

It is possible to speculate that direct service concentrators may have had either less preparation in these areas prior to entering the master's program, lower expectations for receiving such training or less desire for training than did the community organization concentrators. Therefore, direct service concentrators may have been more satisfied with the amount and quality of instruction they received in these skill areas than were community organization concentrators. If this were the case, a smaller amount of exposure to various community organization/planning skill areas would probably meet the educational objectives of direct service concentrators, whereas community organization concentrators may have felt they should have received more intensive training. In addition, it is likely that community organization concentrators have realized the need for more expertise in these skill areas as a result of the demands of their types of practice situations since graduation.

Like the procedure used to determine significant differences 
Detween grouf means on the skill ratings, a series of $t$ tests were made on the average scores of School of Social Work contribution to skill attainment. Since the responses given in this section were coded as either a "1" for DID contribute or "2" for DID NOT contribute, all group means had to fall between 1 and 2 .

Statistically significant differences, at the .05 level, were found for several items which appear in Table 16.

TABLE 16

SIGNIFICANT DIFFERENCES BETWEEN GROUP MEANS ON SCHOCL'S CONTRIBUTION

\begin{tabular}{lcccc}
\hline \hline Skill & c.0. & $\frac{\text { Means }}{\text { Direct service }}$ & $\begin{array}{c}\text { Degrees of } \\
\text { freedom }\end{array}$ & $\begin{array}{c}t \\
\text { score }\end{array}$ \\
\hline $\begin{array}{l}\text { Set and adhere to agendas } \\
\text { Knowledge of research } \\
\text { design }\end{array}$ & 2.00 & 1.80 & 36 & 2.064 \\
$\begin{array}{l}\text { Assess interests of parties } \\
\text { in transactions }\end{array}$ & 1.55 & 1.05 & 36 & 4.019 \\
$\begin{array}{l}\text { Supervise, work with para- } \\
\text { professionals }\end{array}$ & 1.83 & 1.45 & 36 & 1.971 \\
\hline
\end{tabular}

On each of the items shown in Table 16, the community organization respondents, as a group, rated the School's contribution to their attainment of the skill significantly lower than direct service concentrators. The first three items are predominantly community organization/planning in scope, yet community crganization concentrators did not feel the School provided them with much training in these areas. Not one community organization concentrator, for example, credited the School with thein mastery of skill in setting and adhering to agendas. On that particular item, there was no 
variance at all among the community organization group.

\section{Sumnary}

The following are the central findings of this follow-up study. of community organization and direct service concentrators:

1. The majority of community organization respondents were practicing in the fields of community organization, planning and social welfare administration. They tended to be in middle-management positions with an average annual salary nearly $\$ 2,000$ above that of direct service respondents.

2. Community organization concentrators, as a group, tended to rate community organization/planning skills as having greater relevancy to their forms of practice than did direct service concentrators.

3. It appears that the type of agency setting or job position of the respondent was a more important determinant of his measurement of skill relevancy than his area of concentration in graduate school.

4. Both community organization and direct service concentrators tended to rate the more generic and nontechnical skills higher than the skills that were more job-specific and technical.

5. Community organization concentrators tended to credit the School of Social Work with contributing to their attainment of community organization/planning skills less frequently than did direct service concentrators.

Thus, the findings suggest that certain skills of a community organization/planning nature are generic to both community organization and direct service concentrators. While community organization concentrators generally rated the community organization/planning skills as having greater relevancy to their practice following graduation than direct service concentrators, the latter did indicate need for expertise in a number of these areas.

The type of social work practice respondents became engaged in following graduation appeared to exert a greater influence on 
how they rated community organization/planning skills than their area of specialization in the master's program. Since both groups, by and large, secured employment in fields corresponding to their area of concentration in graduate school, their respective type of specialization was appropriate for practice performance.

That community organization concentrators tended to credit the School with contributing to their expertise in the various communty organization/planning skills less often than direct service majors may reflect their feelings that they did not receive sufficient training in the kinds of skills they have been called upon to demonstrate in actual practice since graduation. This would be particularly true of the community organization respondents who were students during the early years of the community organization program when the curriculum and range of appropriate field placements were very Iimited.

In addition, it was found that community organization concentrators overwhelmingly (73\%) would have preferred "block" field placements, that is four days a week during certain quarters versus the present format of two field days per week concurrent with classes. They favored "block" placements because they would enable students to become more involved in their agency settings and prevent fragmentation of assignments.

In terms of their views on the community organization, on Social Welfare Planning, methods requirements and scheduling, the community organization concentrators were fairly evenly divided on their opinions. Twenty-eight percent of the respondents approved of the 
present six-term methods sequence, while $22 \%$ felt that second year methods should not be required and $33 \%$ preferred a more individualized program combining required methods and elective courses appropriate to the student's needs and interests.

Further, a number of community organization concentrators recommended that stronger emphasis be placed on social welfare management skill development in the Social Welfare Planning option. They felt more course and field work should be focused on techniques of organizational change, budgeting, systems analysis and operations, program development and evaluation and research design. While these same skills tended to be rated, by both groups, as having less relevance to the jobs they have held since graduation than many others, respondents may be indicating that they could be utilizing these skills had they had adequate training in these areas, or that they anticipate these skills becoming increasingly more necessary for practitioners in the fields of community organization and planning. Lastly, a number of community organization respondents feit that graduate social work education should increase the student's ability to analyze and work effectively within the political and economic realities affecting their practice. To provide social work students with more adequate exposure to these various skill and knowledge areas, many respondents suggested that social welfare planning concentrators be encouraged to enroll in more courses offered by other departments in the university such as Urban Studies, Systems Science and Business Administration and that certain social work courses by "cross-listed" with these departments. Such steps 
would provide social welfare planning concentrators with a more interdisciplinary approach, broaden their knowledge base and maximize university resources. 


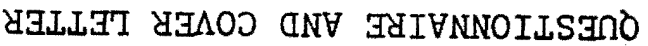

$\forall$ XIONAdd 
November 27, 1973

Mrs. Hedy-Jo Powell

10793 S. W. Murdock Apt. B-11

Tigard, Oregon 97223

$(503-639-0371)$

Dear

The Portland State School of Social Work recently adopted a curriculum structure that provides planning option, with facilitative services available as a sub-option on an elective basis. The school is making changes in its structure to better meet the needs of those students desirous of a career in community organization and social welfare planning.

The attached questionnaire is part of a research practicum aimed at identifying community organization and planning skills that M.S.W.S are being called upon to perform in their actual practice. This questionnaire is being sent to all graduates of the School who concentrated, to some degree, in community organization. In addition, it is being sent to an equal number of non-community organization majors whose names were drawn from a random sample. We are interested in learning what community organization and planning skills are being used by both groups.

Your careful and honest answers will help us to evaluate the current curriculum and design the new social welfare planning component.

Please complete the questionnaire and return it to me as soon as possible. Enclosed is a self-addressed, stamped envelope for your convenience. Your cooperation will be greatly appreciated.

Sincerely,

Hedy-Jo Powell 
I. BIOGRAPHICAL AND BACKGROUND INFORMATION

1. Your age year

2. Your sex (Imale ()female

3. What was your undergraduate major?

() Social work/social welfare

() Social sciences

( )psychology

() sociology

()history

()economics

() Physical sciences

() chemistry

()physics

()Biological sciences

()biology

() zoology

()English/literature

()Foreign languages

()Mathematics

()Fine arts

()Education

()other (please specify)

4. What was the time span between receiving your Bachelor's degree and enrollment in the School of Social Work? years.

5. How much social work employment did you have prior to enrollment in the School of Social Work? years.

6. In which type of social work practice was this employment?

()NO prior experience

() Direct services

() Community organization or social planning

()Facilitative (e.g. supervision, administration, teaching)

7. Have you had other social work related experience e.g. Vista, Peace Corps, volunteer and club work. ()yes ()no

8. While in the master's program, did you concentrate in the Community Organization courses?

()yes ()no 
9. IF you answered YES to the last question, when did you decide to concentrate in community organization and planning?

()Before enrollment in the School

()During the first year

()After the first year

10. Briefly, what influenced your decision to concentrate in community organization (indicate if you DID NOT concentrate in community organization).

II. EDUCATIONAL EXPERIENCES

11. Where was your first year field placement

12. Was this regarded as a Community Onganization/Planning placement? ()yes ()no ()don't know

13. Briefly, what types of activities, assignments were you involved in during your lst year field work?

14. Where was your second year field placement?

15. Was this regarded as a Community Organization/Planning placement? ()yes ()no ()don't know

16. Briefly, what types of activities, assignments were you involved in during your second year field work? 
17. Please list the community organization courses, by title or main subject matter, that you took that were offered by the School of Social Work. (Please indicate if you did not take any designated community organization classes)

18. Please list any community organization or planning courses or conferences that you enrolled in that were offered by D.C.E. or other departments.

III. EMPLOYMENT INFORMATION

19. In what year did you receive your M.S.W.?

20. What has been your employment history SINCE graduation from the School of Social Work? (Please fill in the table)

Employer Job Title

Dates of Employment

$\begin{array}{ll}\text { From } & \text { To } \\ \text { From } & \text { To } \\ \text { From } & \text { To } \\ \text { From } & \text { To }\end{array}$

21. Are you presently employed in some form of social work practice? (i.e. direct services, planning, supervision, etc.) ()yes ()no

22. Please give the name of your employer, 1.e., name of agency or firm.

23. What is your present salary? \$

IV. RELATIONSHIP OF SKILLS TO JOB REQUIREMENTS

Instructions

The following is a list of skills and areas of knowledge often associated with community organization and planning practice. We are interested in determining how important these skills are to both community organization and direct service majors. Please consider each item in terms of its relevancy to the jobs you've held since receiving you M.S.W. then circle the number, on a scale of $O$ (no importance) to 5 (high importance) 
that best describes each item's importance to your employment.

For example, if one-to-one interviewing of clients is regarded as as essential skill and major activity in your practice setting, circle the "5".

63. one-to-one interviewing

$$
\begin{array}{llllll}
0 & 1 & 2 & 3 & 4 & 5
\end{array}
$$

with a client

24. Establish working relationships with

citlzen groups................... 1 . 2345

25. Motivate and sustain group or individ-

ual involvement and interest in a

goal or plan..................... $12{ }^{2} 345$

26. Build leadership qualities in others

and replace self as leader........... 122345

27. Plan and conduct meetings, workshops

or conferences................... $123{ }^{2} 4$

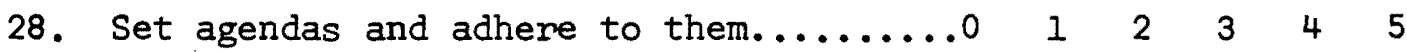

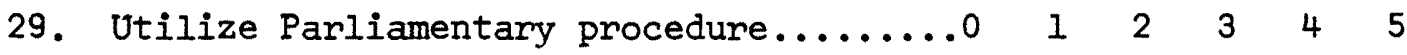

30. Pull out or crystallize issues from a group discussion and articulate them....0 $1 \begin{array}{lllll} & 2 & 3 & 4 & 5\end{array}$

31. Possess knowledge of research design and methodologies................. $12{ }^{2} 345$

32. Set objectives and lay out tasks to meet these objectives............... 122345

33. Ability to analyze the community political structure................ 123345

34. Skill in fact-finding, analysis of demographic and survey data........... 122345

35. Knowledge of the legislative processes (local, state, federal)............. 122345

36. Knowledge of social service delivery systems........................ 123345

37. Have extensive expertise in at least one issue area (housing, welfare, health, economic development)......... 122345 
38. Knowledge of organization theory;

analysis of organization.............. 122345

39. Accurately assess the interests and committments of parties in a trans-

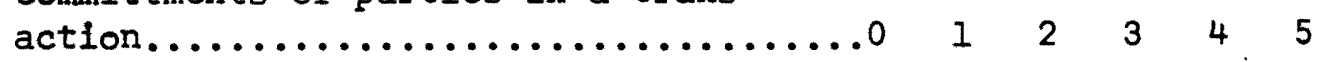

40. Perform "broker", arbitrator or negotiator roles................... 122345

41. Promote consensus between individuals and/or groups..................... 122345

42. Enlist the support of key community and/or political figures.............. $12{ }^{2} 34^{4} 5$

43. Possess a working knowledge of cost benefit, planning, programming budgeting systems.................. $120^{2} 34$

44. Develop new programs................ 1 . 2 3 45

45. Prepare program budgets.............. 1 . 2 3 45

46. Knowledge of state and federal funding sources and application procedures...... $010 \begin{array}{lllll}1 & 2 & 3 & 4 & 5\end{array}$

47. Devise feedback systems to provide program information for management purposes........................ $123{ }^{2} 45$

48. Ability to "abstract" research

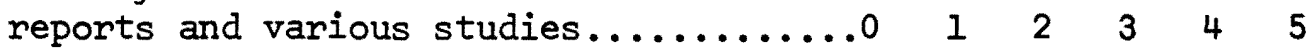

49. Serve as "staff" to board, committees, or task force groups................ $120^{2} 34$

50. Write a grant or proposal............ 1 2 3 45

51. Design and implement measures for program evaluation................. 122345

52. Supervise, or work closely with paraprofessionals.................... 123 345

53. Organize staff and allot manpower resources efficiently............... 122345

54. Utilize "P.E.R.T." techniques to show project tasks related to time and manpower..................... 122345 
55. Develop and be prepared to argue

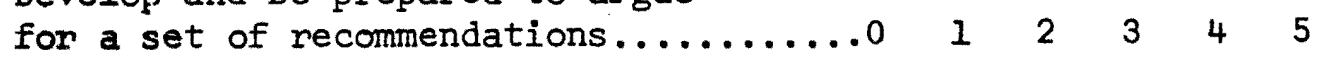

56. Identify "target" groups or individuals and plan strategies to deal with them...0 1223045

57. Utilize Management-by-objectives, from program level down to staff level....... $1 \begin{array}{lllll} & 2 & 3 & 4\end{array}$

58. Plan and conduct staff development on in-service training................ 122345

V. ASSESSMENT OF SCHOOL'S CONTRIBUTION TO SKILL ATTAINMENT

Piease turn again to the list of skills (items 24-58) and circle the numbers of those skills which you feel the School of Social Work helped you to attain. For example, if you feel your graduate educational experiences contributed significantly to your attainment of skill in social research, circle 32. Circle the numbers of those items to which either course or field work contributed substantially.

Thank you for your participation!

Please mail the questionnaire immediately.

VI. RECOMMENDATIONS (Community Organization Majors only)

56. Looking back at your field work, would you now prefer

() 2 days per week, per term, concurrent with classes.

()"block" placement, 4 or 5 days per week for several terms, with only methods course.

() other

57. At present, methods is required each of the 6 terms. How do you feel about this requirement?

() approve; good sequence.

() no methods should be required in second year.

() other

58. Your suggestions for new course offerings, or subjects to be included in the Social Welfare Planning option would be most heipful. Please use the remaining space to outline what you would like to see included in graduate education for community workers and social planners. Suggestions for changes in sequences, scheduling of field and course work, etc. are welcome. 
BUIVNNOILSARO INGQRLS S, RMOT

g XIGNGddV 
Student Questionnaire

School

To the Student:

This questionnaire is designed to gather information on your views of your education and training experiences in social work. It is being given to students in schools in the United States and Canada. Your careful and honest answers to the questionnaire may help social work educators to evaluate and reform educational programs.

The first parts of the questionnaire contain agree-disagree type items. These do not give you a chance to express the qualifications of your answers and the subtleties of your opinions. But the last part enables you to convey in depth your ideas about important ways social work education might be improved.

You as a student are in a unique position to answer these questions. Your educational experiences are fresh in your mind and you have taken courses with many different faculty members in various areas of the curriculum. Therefore, your participation is essential in gathering needed information on social work education.

Thank you in advance for your participation.

\section{Biographical Information}

Please check or fill in the following:

1. Age years

2. Sex: Male Female

3. Are you a first- or second-year student?

First Second

4. Are you now a full-time student? Yes - No

5. On what field of social work will you concentrate your study? Casework Group work Community Organization

Research Adminis tration

Other (please specify)

6. What was your major in your undergraduate work? Check one.

1. Social Science (e.g. psychology, sociology, anthropology, history, economics)

2. Social Work or Social Welfare

3. Physical Science (physics, chemistry)

4. Biological Science (zoology and biology)

5. English and Literature

. Foreign Language

. Mathematics

8. Fine Arts

- 10. Other 
7. What was your grade average in undergraduate studies?
At
$\mathrm{Bt} \quad \mathrm{C}+$
$\mathrm{A}-\longrightarrow \quad \mathrm{B}-\square$
C
C
C- or lower

8. What is (was) the occupation of your father or main provider? 1. Professional person (e.g. doctor, teacher, lawyer, minister, scientist)

2. Proprietor, manager, or officer (e.g. owner, banker, Army officer, city or union officer)

3. Clerical sales and kindred worker (bookkeeper, secretary, insurance agent, or salesman) 
"SLdGONOO NOILOV" NOILVZINVDYO RLINAWWOO

0 XIGNJddY 


\section{COMMUNITY ORGANIZATION ACTION CONCEPTS}

1. Interprets client to others in terms of activities, purposes and proposals.

*2. Interprets worker's function to group.

3. Interprets function of agency to group.

*4. Gives interpretation of process toward goal.

5. Interprets purpose and structure (of intergroup).

*6. Interprets blocks in progress toward goal.

7. Interprets constantly other group's functions.

8. Interprets interaction.

9. Spreads the consciousness of need.

1.0. Encourages awareness of latent problems.

11. Enables identification and examination of one's own interest in social goals and problems.

12. Recognizes when conditions are favorable to enlist cooperation for an advance on a particular front.

*13. Focuses discontent of client.

*14. Heightens awareness of social responsibilities.

*15. Advises on problem solving methods.

16. Gives suggestions.

*17. Serves as an expert to clients.

18. Enables participation in identifying social problems.

19. Enables group to discover, modify or discard social goals.

*20. Helps carry out social goals.

21. Emphasizes common goals.

*22. Enables participation in selecting social goals.

*23. Initiates and facilitates process of identifying discontent.

24. Promotes consciousness of need.

*25. Helps client verbalize discontent.

26. Helps the agency to strengthen its program of interpretation to to community.

27. Enlists the interest of key persons in the community.

28. Suggests the relationship between the work of the agency and the well-being of the community.

29. Arranges interviews with organizations to give them some information about the work of his agency.

30. Board and staff have responsibility in public relations.

31. In public relations - speaks to groups, contacts the press.'

32. Gives content to the board meeting by enhancing the capacity of individual members to contribute effectively to the group's deliberations.

*33. Develops relationships with the board and with the committees created to assist the board.

*34. Records and analyzes social data.

35. Collects and publishes financial and service data pertaining to the work of its member agencies.

36. Encourages realistic appraisal of problems.

37. Focuses desires for action.

38. "Directs" social resources to meet welfare needs. 
39. Indicates plans for the forthcoming year.

40. Compiles directories of social welfare services.

41. Annual report - advances the community organization objectives of the agency.

42. Coordinates existing treatment facilities.

*43. Examines the service program of his (own) agency to make sure it is being competently administered.

44. Provides data that will enable the community to evaluate the work done.

*45. Clarifies roles.

*46. Strengthens awareness of roles.

*47. Stimulates feelings of need in client for more adequate life.

48. Suggests alternatives to present conditions.

$* 49$. Encourages organization toward the solution of problems.

*50. Helps select social goals.

51. Develops programs.

52. Investigates.

53. Makes a social study.

54. Engages in experimentation under controlled conditions.

55. Directs research and interprets findings to the community.

56. Conducts surveys to determine whether social service needs in the community are reasonably well met by the existing programs of the agencies.

*57. Seeks to help the group to exercise the most effective quality of leadership it can develop.

58. Clarifies issues.

*59. Gives support to clients.

60. Enables person to help his group identify and examine own interest in social goals or problems.

*61. Acts as resource person.

*62. Functions as an enabler.

*63. Enables group to interact with other groups represented in terms of social goals.

*64. Encourages discussion.

*65. Acts as communication link.

66. Assembles data in order to help people to ascertain what a particular community needs and how its needs may be met.

67. Studies the local situation to determine whether a need exists which might be met through the development of a program.

68. Seeks to develop new methods and new interests out of the elements of knowledge with which the group is already familiar.

69. Cultivates favorable sentiment for a new program before the program is imposed upon the community.

70. Develops public support of, and public participation in, social welfare activities.

*71. Establishes professional relationship.

*72. Helps people see commonality of feelings.

*73. Gives factual information to group.

74. Gives support to efforts to deal with problems.

*75. Adjusts material to audience - begins where they are in their thinking. 
76. Enables client to develop group bond of strength sufficient only to maintain operations adequately.

77. Encourages individuals and groups to pool their resources and efforts to achieve an improvement in group life.

78. Helps group develop suitable structure and operating practices.

*79. Helps person understand group or groups.

80. Draws persons of diverse talents and interest into an organic relationship with the total program.

81. Develops skills in stimulating group thinking and in motivating group action.

82. Establishes channels through which groups may communicate and react upon one another.

*83. Helps people relate themselves to the group quest for social integration.

84. Promotes the cooperation of groups.

*85. Provides means by which individuals may identify with groups in the interest of enhancing the effectiveness of their personal contribution.

86. Enables group to form, function and disband.

87. Discusses and interprets role of intergroup to group.

*88. Helps groups respond to the significant changes in community life.

89. Understands individuals, groups represented and relations between the individuals.

*90. Nourishes interpersonal relationships.

91. Helps individual to gain or lose status in intergroups.

*92. Helps individual to present and represent his group adequately.

*93. Helps client to overcome resistance.

*94. Helps people look at themselves.

95. Helps client to release feelings.

96. Is a guide to help client establish and find means of achieving own goals.

*97. Involves client in working on problem.

*98. Helps individual to understand nature of the process in which engaged.

99. Helps individual to perform role as representative.

*100. Helps individual to understand other member and groups they represent.

101. Helps individuals to face personal problems if they block intergroup process.

102. Shows acceptance of individuals and ideas.

*103. Establishes rapport with client.

104. Helps person to examine viewpoints of others and to act and react responsibly.

*105. Enables individual to establish and maintain responsible relation with groups he is representing.

*106. Helps client to grow in personal and social understanding.

107. Enables client to clarify ideas and express own goals.

108. Analyzes problems currently confronting the agency and the community.

*109. Evaluates. 
*110. Uses self-knowledge ably and professionally.

*111. Analyzes.

112. Compromises on basis of tentative progress.

113. Asks questions to stimulate insight.

*114. Enables inaividual to understand, accept and perform role consistent with role as representative.

115. Administers.

116. Promotes voluntary agreement through negotiation.

117. Operates joint services.

118. Recruits and trains new personnel.

119. Promotes legislation.

120. Proposes specific social programs to legislators.

121. Promotes social action.

122. Advances a cause through personal contacts with officials, political leaders and other persons and groups.

*123. Develops and uses group discussion, the conference process, and committees.

124. Promotes interagency consultation.

125. Plans.

*126. Controls recording on a community-wide basis.

127. Records case material.

128. Further develops mutually satisfactory relations between groups represented (in terms of selected social goals).

129. Enables communication "from and to" intergroup.

*130. Enables selection of suitable representatives to the intergroup.

131. Shares in responsibility of intergroup to develop functions, structure and operating practice.

132. Interviews.

133. Confronts.

*134. Gives evaluation of goal-directed process.

135. Helps client evaluate accomplishment.

136. Accounts for funds spent.

137. Raises funds.

138. Carries out financial campaigns.

139. Budgets. 
STIIXS NOIJVZINVDYO XIINNWWOO S، YZGNVTGIIYA

a XIQNGddV 
COMMUNITY ORGANIZATION PRACTICE IN SOCIAL WELFARE

\begin{tabular}{l} 
Means \\
\hline I. SOCIAL WORK COMMUNITY \\
ORGANIZATION METHOD \\
Generic ele- Specialized \\
ments of the elements of \\
three social + community \\
work organization \\
methods \\
II. OTHER MEANS \\
1. Facilitating Processes \\
Administration-board develop- \\
ment, budgeting, policy- \\
making, and so on \\
Supervision-formal and informal \\
Other coordinating techniques \\
2. Educational Methods \\
Conferences, forums, workshops \\
In-service training \\
Interdisciplinary understand- \\
ings and coordination \\
Teaching, student field work \\
Committee projects \\
3. Research Methods \\
Research \\
Systematic study \\
Fact-gathering \\
4. Social Action, Social Reform
\end{tabular}

5. Consultation
6. Fund Raising
Recruiting and training leader- ship
Developing campaign structure, methods, techniques
Financial accounting to donor public

I.

Ends
1. Change toward meeting health and welfare needs more adequately, and more cooperative and effective means of accomplishing these goals

II.

1. To facilitate communication, coordination, develop appropriate structure, controls, intraagency, interagency, and intercommunity

2. Change in values, extend knowledge, gain understandings, professional improvement, informed citizen leadership, improved programs and service standards

3. To provide answers to questions posed, and to provide basis for decision-making and courses of action

4. To effect changes in legislation, in social policy, and in community structure to meet social welfare needs

5. Making knowledge, advice, experience available to others under their auspices and responsibility as they choose to use and implement

6. To provide money and leadership for health and welfare causes 
COMAUNITY ORGANIZATION PRACTICE IN SOCIAL WELFARE (Continued)

\begin{tabular}{|c|c|}
\hline Means & Ends \\
\hline $\begin{array}{l}\text { 7. Publicity, Public Relations } \\
\text { Public information media, } \\
\text { speeches, press, radio, TV } \\
\text { 8. Negotiation, Arbitration } \\
\text { Other strategy techniques }\end{array}$ & $\begin{array}{l}\text { 7. To develop the climate and } \\
\text { understanding necessary for } \\
\text { community support and interest } \\
\text { in health and welfare programs } \\
\text { 8. To effect strategic changes } \\
\text { in community or agency power } \\
\text { structure toward improved } \\
\text { health and welfare programs }\end{array}$ \\
\hline
\end{tabular}

SOURCE: Walter A. Friedlander, ed., Concepts and Methods of Social Work (Englewood Cliffs, N. J., Prentice-Hall, 1958), p. 226. 
INITLDO STIIXS XIISYZAINO VIGWNTOO

a XIQNGddV 


\section{SKILIS}

The field placement should enable the student to engage himself in the actual practice of community organization and its application as a method of social work. It is in this area that the student demonstrates through the actual involvement with individuals, groups and communities (supported by recording and supervisory conferences), that he has the wherewithal and requisite skills to achieve an acceptable level of professional practice.

\section{THE SKILLS OF THE COMMUNITY ORGANIZER}

There are five broad areas of skill which C.0. students are required to master: (1) relationship or engagement skills, (2) organizational or group management skills, (3) analytic skills, (4) strategic or political skills, and (5) administrative skills.

I. Relationship or Engagement Skills

This is the set of skills most typically associated with the social work practitioner. There are, however, significant differences (in degree if not in kind) between the skills required of the community organizer in this area, in contrast to his peers in the other methods. Two may be cited: Organizers must understand and be responsive to the behavion of persons in their roles as members of community collectives, rather than as "total personalities."

Some examples of relationship skills important to the organizer are as follows:

a. Ability to observe -- picking up non-verbal expressions which indicate how the client is reacting to the exchange, who he "represents," his role in the group, etc.

b. Ability to listen and to hear -- understanding and using overt and covert cues, discovering and dealing with "hidden agenda's when they exist (and knowing when they do not).

c. Demonstrating interest in, identification with, and commitment to clients and to the issues of importance to them. Acceptance of client differences and of people's own aspirations. Ability to work with people of differing life-styles.

d. Communicating in ways meaningful to clients, including ability to elicit client feedback.

e. Searching for and defining a focus which takes into account concerns of both client and worker as well as their respective goals, roles, and expectations for one another.

f. Ability to confront tense situations with self-discipline (This implies neither seeking to express one's own anger for personal reasons, nor avoiding hostility because it is discomforting. 
g. Ability to be direct and honest in interaction with clients, and to deal with feelings as the situation may require.

h. Ability to interest clients and motivate their involvement.

Some of the above imply personal characteristics which are desirable, or even mandatory, on the part of the organizer. We wish to specify three of these, because of their importance to effective community organization practice: (1) Conscious use of self. This is a traditionally required capacity in social work practice. Personal self-awareness is important so that one's personality does not interfere with the pursuit of client need. We would also stress the importance of understanding the impact of agency role, group structure and community context upon one's reactions and attitudes as an element of conscious use of self; (2) Innovation. Community organization, as a method which requires attention to institutional modification, requires practitioners who, while they may not necessarily dismiss the old, are comfortable in the search for the new, and open to its possibilities. An innovative person, we note, is often a critical one; (3) Independence and responsibility. A lack of structure is inherent in many c. 0. tasks. This requires practitioners who are sufficiently comfortable with lack of structure, self-generating, and able to live with ambiguity.

\section{Organizational or Group Management Skills}

Broadly characterized, these are the skills required to develop, build, and sustain a constituency in ways allowing the pursuit of program which makes an impact upon social problems. Since professional means have a tendency to become ends in themselves, we risk stating the obvious. Organizational or group management skills, as indeed relationship and other skills as well, are professionally salient only as they are related to the pursuit of client-worker objectives.

Some examples of group management skills are:

a. Ability to identify problems, crystallize issues, and develop specific goals from sometimes vague and diffuse expressions of client interest or need.

b. Ability to operationalize goals into program activities -assessing readiness and capacity, motivating interest, identifying tasks and resources, and guiding actions.

c. Ability in establishing or shaping group structure which is consonant with client capcity and interest, contributes to the achievement of client-worker goals, and facilitates the execution of program tasks.

d. Ability to plan and conduct conferences, campaigns, and demonstrations.

e. Ability to plan and conduct group meetings -- including 
preparation, agenda setting, devising relevant and meaningful program content, encouraging interaction, identifying next steps, and conducting appropriate follow-up.

f. Ability to relate worker activity and role to the objectives of the effort and the expectations and needs of the group.

g. Ability to choose priorities and weigh the balance among vying needs concerns, e.g., focus on an issue, group development needs, individual needs, etc.

\section{Analytic Skills}

Rational problem-solving is important in all of social work, but nowhere more so than in its planning and policy analysis functions. They require analytic ability of a relatively high intellectual order. (Although this statement does not deal with the knowledge requirements of the organizer except as all skill is, of course, based upon the application of knowledge), it is worth noting that the planning and policy functions of the organizer requires extensive substantive knowledge in the particular problem area receiving attention. We suggest that, upon graduation from a school of social work, an organizer should have extensive knowledge in at least one issue area, e.g., education, housing, welfare, economic development, etc.

Examples of analytic skills are:

a. Ability to describe and study a situation or problem, to assess past efforts in dealing with it, and to identify additional data or information which may be required, its source and/or means of collection.

b. Ability to define a focus relevant to central issues, and which incorporates (implicitly or otherwise) an assessment of the opportunities and constraints posed by the context of the situation (e.g., the interests of the employing agency, the stakes of other interest groups, etc.).

c. Ability to organize and systematically address the range of goals, strategies, and resources which may be devised to "solve" the problem.

d. Ability to develop well-ordered and cogent argunents for one set of recommendations to deal with the problem or situation.

e. Ability to specify in detail the tasks which need to be performed, by whom, and with what resources and procedures.

4. Strategic or Political Skills

"To engage in planned collective action in order to make an impact upon social problems" requires strategic skill. The organizer, 
in pursuing client interests, is engaged with "actions systems" which are varyingly committed to client goals and with "target systems" which are the object of the change attempt. To deal effectively with these groups requires political skill.

Some examples are as follows:

a. Ability to assess the interests and commitments of the parties in the transaction, and to relate one's objectives to the intensity of the respective commitments, as well as to other factors.

b. Ability to identify sources of influence, one's own and one's adversary's, to enhance one's own power or the appearance of it, and to minimize the threat of the adversary.

c. Ability to strengthen the cohesiveness of one's constituency, while searching for an adversary's sources of disunity, including the location and nurturing of appropriate coalitions.

d. Ability to identify and use areas of conflict and converging interest among the parties, including facility in dealing with the dialectics of conflict action-reaction, ability in conflict management and in the promotion of consensus.

e. Persuasiveness in both verbal and written communication. This includes an ability to make an effective public case for one's position, including the shaping of one's argument to the perspectives of one's audience.

f. To communicate with adversaries in ways which increase one's options and in the context of one's objectives, e.g., to imply rather than state, to threaten with appearing to do so, to be firm when firmness is required, etc. This includes the ability to appeal to what may be positive in a potential adversary.

g. Skill in negotiation, including the formulation of demands, the balancing of reasonableness and obstinacy, and the location of satisfactory compromise positions (i.e., obtaining as much as is achievable with as little cost as possible).

5. Administrative Skills

In its broadest sense, administration requires two seemingly contradictory objectives: (1) insuring compliance to agency goals, programs, and policies, and (2) insuring change in organizational goals, programs and policies to meet new perspectives or conditions. Administration is also viewed more specifically as encompassing a series of specific components or techniques, such as personnel and financial management. It is in both these senses that an organizer must be skillful. 
Some of the more important examples of administrative skill are:

a. Ablity to encourage agency sanction for programs, policies, or efforts which meet client needs and interests "Sanction," it should be noted, is here broadly defined to mean achieving the freedom or even lack of surveillance to pursue client-oriented efforts, even when explicit support is not forthcoming). The above implies an understanding of the organization as a social system, and ability to "negotiate" the system in onder to maximize client-oriented behavior.

b. Skill in participation in group decision-making and program planning, including contribution to staff meetings and training sessions, and the ability to use the contribution of others.

c. Ability to learn and to teach. Effectiveness in the development and use of training and supervisory processes, including work with paraprofessionals.

d. Ability to establish effective working relations with superordinates, peers, and subordinates. This implies both tolerance for difference and the ability to maintain and effectively promote one's own viewpoint.

e. Ability to establish appropriate prioritles in one's work, and to use time effectively and efficiently.

f. Ability to write records, minutes, and reports which capture the essence of the process, decision, or position. 


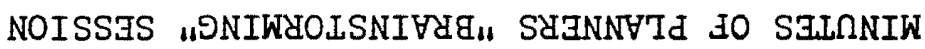

I XIONGddV 


\section{PLANNERS "BRAINSTORMING" SESSION}

November 14,1973

The following is the product of a group assembled to "brainstorm" about the shape and scope of the social welfare planning aspect of soclal work education. The group consisted of the sub-committee on Social Welfare Planning of the Curniculum Policy Committee, those who are currently teaching in this option and a group of planners specially invited to this meeting.

To give focus to our discussion, we addressed ourselves to the following questions:

1. What do planners do these days?

2. What skills are required in planning?

3. What bodies of knowledge must be explored?

4. How should future planners be educated?

It was understood by all present that this document would play an important role in planning the new social welfare planning curriculum of the school.

\section{What Planners Do}

In a sense every practitioner is a planner. Planning is one aspect of administration and every practitioner is called upon to participate in the administration of the program and the agency of which he is a part.

Those who think of themselves primarily as planners in the field of social welfare can be found in both the public and private sectors. In the public sector they work at all levels; national, in state agencies and with the legislature and in the counties and the cities. In the private sector they are found in community councils, federations and private agencies.

Planning Tasks

Among the tasks that planners are involved in are the formulation of social policy, social problem analysis, long- and short-range forecasting. They are involved in processes of achieving accountability. They are often involved in questions of jurisdiction, that is, defining a system's or sub-system's "turf."

In terms of processes, they are called upon to conceptualize and to simplify problems; they are expected to produce outcomes in the form of reports, recommendations and implementation plans that lead to better services for people. 
Realities

There are a number of realities which must be recognized by the practicing planner and should be taught to the future planner.

Above all, it should be emphasized that we plan in a dynamic world. There is no way that we can stop the world, get off and do some planning. Life goes on as we do our planning; the ground is continually moving underneath our feet.

Secondly, because planning is necessarily change and future oriented, planners are involved in dealing with unclarity and uncertainty. It is important, also, to realize that change is usually made in small increments although there may also be a special purpose for farreaching change of the type represented by the new plan for service delivery now being promoted for Multnomah County.

If planning is to be effective, it must have administrative support. Current Preoccupations and Trends

The planner needs to be aware of current fashions and fads in planning, to be able to evaluate their values and liabilities. Currently, for instance, there appears to be a trend from line-item budgeting to planning and budgeting by objectives. New agencies are developing which group prior agencies and services by the type of problem they address. Budgeting provides a certain percent for a particular area of service. Mixed funding sources for programs is becoming more common. Federations of service deliverers, as for example the Regional Alcohol Board, are being formed.

Principles of Planning

While this was not the focus of our concern, a number of planning principles and strategies were discussed. The approaches of compromise and advocacy were compared and contrasted. The "enabler" approach was mentioned. Concensus, which was seen as the "western" U.S. approach, was compared with the "conflict" model, which was seen as "eastern." We should be looking, always, for approaches that lead one to a specific end.

It was recognized that these can be and is planning both for inputs and outputs. Unless one has control of both, one cannot be held accountable both for inputs and outputs.

One of the participants indicated that in their planning they found themselves adapting a four-way perspective on 1) time; 2) program; 3) people; and 4) data.

II. Essential Skills and Knowledge

An important task of the evening was to brainstorm about the types of 
skills and knowledge planners should have or will be called upon to demonstrate in actual practice. The following skills, which have not been prioritized, were regarded as highly valuable:

A. Administrative skills. The ability to be a manager, to understand personnel practices, utilize management by objectives techniques were stressed. This area includes communication skills, supervisory expertise, and the ability to produce clear, concise written reports. Time pressures necessitate skill in abstracting research reports, studies, manuals, etc. Central ideas and issues must be "pulled out" by the planner. Many times the planner must develop an oral or written presentation from reports, studies, etc. and make recommendations for action. Of increasing importance is knowledge of budgeting and information systems. Planning, programing, budgeting, cost/benefit analysis and other systems are being applied in the human services field.

B. Research Skills. There is need for persons who can design research studies. The planner must decide what information is needed and set up procedures to gather data, analyze it and suggest plans of action. The group seemed to emphasize the value of "leg" work and practical experience in research prior to seeking a planning position, per se. Skill in research design received more attention than expertise in statistical computation.

C. The ability to analyze. The planner must be sensitive to the political, onganizaticnal and interonganizational climates in which he operates. Planners should possess an understanding of both the "administrative mind and role" and the "people world." Those in planning positions need to be able. to diagnose the sources of power and influence from all sectors of a community and seek support from these leaders. One must be able to function in a "political arena." The planner should be able to analyze the commitments of parties in a transaction. Strategic skills are va?uable.

D. Small group leadership skills. This area covers the ability to plan agendas and conduct meetings. Skill in parliamentary procedure was mentioned. Conference skills include planning and/ or conducting workshops and conferences, recording and analyzing. often planners are involved in getting citizen participation or selecting advisory or policy-making boards. The ability to serve in a "staff" role to boards and committees was felt important.

E. Ability to give oral presentations. Planners are frequently called upon to give information, take a stand, or argue for a set of recommendations. Lobbying skills are significant in a variety of practice settings and for the planner's activities in professional organizations (NASW, coalitions, etc.). Planners are called upon to give presentations to agency administrators, elected officials, boards, community groups, etc. 
F. Knowledge of legal aspects. Those involved in planning need an understanding of contracts, the statuatory basis for service and "boundaries." Awareness of legislation and its implications is important. Planners may seek consultation from the legal profession on occasion.

G. Knowledge of legislative processes. It is vital for persons engaged in planning to be well-versed in how government works at the local, state and federal levels. Planning is enmeshed in the legislative processes. Familiarity with the processes and current and proposed legislation are important. The planner must keep his finger on the pulse of legislative action and utilize pathways of input.

H. Grantsmanship. The planner must have knowledge of funding sources. There should be an awareness of what monies are currently available and what types of programs are projected to be funded in the future. It behooves the planner to make solid contacts with key people in state and regional offices to keep abreast of funding possibilities and build support. Given community needs, standing policy and funding possibilities, the planner creates a proposal to address a problem. Grantsmanship requires skills in actual proposal writing and the review and comment processes. The planner must be able to produce a "durable" product. We should not lose sight of the goal of planning programs, i.e. to help people. The social planner must be cognizant of the relationship between social, physical and economic planining.

I. Decision-making and forecasting. Planning, although futureoriented, often takes place incrementally. Decisions tend to be short-term. Decision makes turn to the social planner for conceptualization of issues and alternative courses of action. Gradually techniques for "costing out" programs, projecting multiple year budgets and developing "social indicators" are coming into use. The means to more accurately forecast future needs and implications of decisions would be invaluable to the social planner. The trend is toward "open outcome" planning. Use of more sophisticated budgeting and information systems should increase rationality in decision-making.

J. Program evaluation. Skill in devising service program plans has been discussed above. With the trend toward accountability, the planner plays a key role in helping program managers to set program goals and measurable criteria for meeting those goals. Evaluation serves to determine how, close a program is to achieving its stated goals and signals areas that may need modification. Elected officials, United Fund budgeting committees and others who control the allocation of resources find evaluation a potent tool. 


\section{Personal Qualifications}

It seems quite likely that social planning may require somewhat different personal qualifications from those required of persons engaged in direct social service. We pooled our ideas on what those personal qualifications might be.

Because there is a great deal of uncertainty in planning and because the ground is constantly moving under one's feet, the planner needs a high tolerance for ambiguity and the ability to shift gears rapidly; he needs to be a strategist and he needs to be tactically flexible.

He must be able to relate well with people and particularly to boards and committees; he must be something of a "politician"; he must be sensitive to the social climate.

Because a proper sense of timing is important, the planner must be patient and be able to tolerate delayed gratification.

Other personal characterisitcs including the capacity for self-direction, self-starting and initiative. He must be creative, innovative and imaginative. He must have great wisdom, good judgment and a sense of humor.

\section{Entry into the World of Planning}

Job opportunities for social welfare plenners are not always readily identifiable. Many persons engaged in planning may not think of themselves as "planners." As more governmental units and social agencies are becoming concerned with planning, more job descriptions can be expected to appear for planners.

From our group discussions, it appeared that one must have a "saleable" credential to enter the realm of planning. That credential may not necessarily be an M.S.W. Graduates of Urban Studies, Business Administration and Systems Science are frequently candidates for planning positions.

Potential employers of planning types stress the ability to demonstrate skills in practice. Often persons specialized in a specific service area, e.g. criminal justice, child development, housing, etc. are recruited for planning activities.

Although there was no concensus on what might constitute a "career ladder" for planners, the group hastened to recommend prior experience in research, "staff" work or "on the line" employment. It was suggested that a good place for M.S.W.'s to begin is as an administrative assistant or in a small agency as assistant director. Administration requires planning skills. Top management often looks to "middle management" levels for persons exhibiting planning skills. 


\section{How to Educate Planners}

The principal idea that emerged from our discussion of how planners should be educated was that the educational program should be largely experiential. A number of designs were suggested; including the following:

1. The Smith Model. The first summer consists of a block of field work. That is, one spends their entire time during the summer in the field in an agency or a program. This is followed by nine months of course work and concludes with a second summer block field placement. ( 14 total months)

2. Modified Block Model. It is a combination of block field work, pure academic and some mixture of both.

3. The "Bloodbath" Model. It begins with two months in a planning agency under a staff member for supervision but expected to do the regular work of the staff and be treated as such--to have to produce. This is followed by an educational need assessment. When the several individual need assessments are completed, the academic program for the year is planned for the remainder of the year and implemented. In such a plan one has to use open course numbers and avoid set course descriptions.

Another suggestion that had considerable attention and support was the idea of using performance measures rather than the completion of course requirements as the basis of attesting to competence. A person should be required to demonstrate that he has acquired certain bodies of knowledge and that he can perform certain essential tasks. This was characterized as the "laundry list" approach.

A number of suggestions were made as to the kind of assignments that might be appropriate in the field. 1) Staff a committee; 2) coliect data and analyze it; 3 ) go from problem to program; 4) recommend a change in a current service delivery system; 5) develop a new program or 6) negotiate a position, etc.

During the field work aspect of the program, there ought to be on-going seminars bringing together the students from all the field settings.

\section{Who Should Educate Planners}

Finally we turned our attention to the educators and first tried to identify the professions and disciplines needed to provide a comprehensive program. In addition to those who' were familiar with the field of social welfare, we recognized a further need for:

System analysts

Physical planners

Lawyer-politician--political scientist

Researcher-applied statistician 
Social problem conceptualizer--social historian--social philosopher

Economist--accountant--budgeter

Porecaster

Businessman

English major

Like the students, the educators would need to have similar qualifications so as to serve as role models but would also need to be able to:

1) order diversity

2) order and reorder academic content quickly, without loss of quality

3) work in a collaborative and interdisciplinary manner

Where are they to be found?

We might consider using practicing planners to teach; we should utilize the full resources of the University; and we should use community people as needed and appropriate to the on-going educational assessment. 
APPENDIX G

TABLES OF GROUP MEANS AND THE VARIANCE AROUND

THE MEANS ON SKILL ITEMS 
TABLE 10

COMMUNITY ORGANIZATION SAMPLE GROUP MEANS AND VARIANCE AROUND THE MEANS

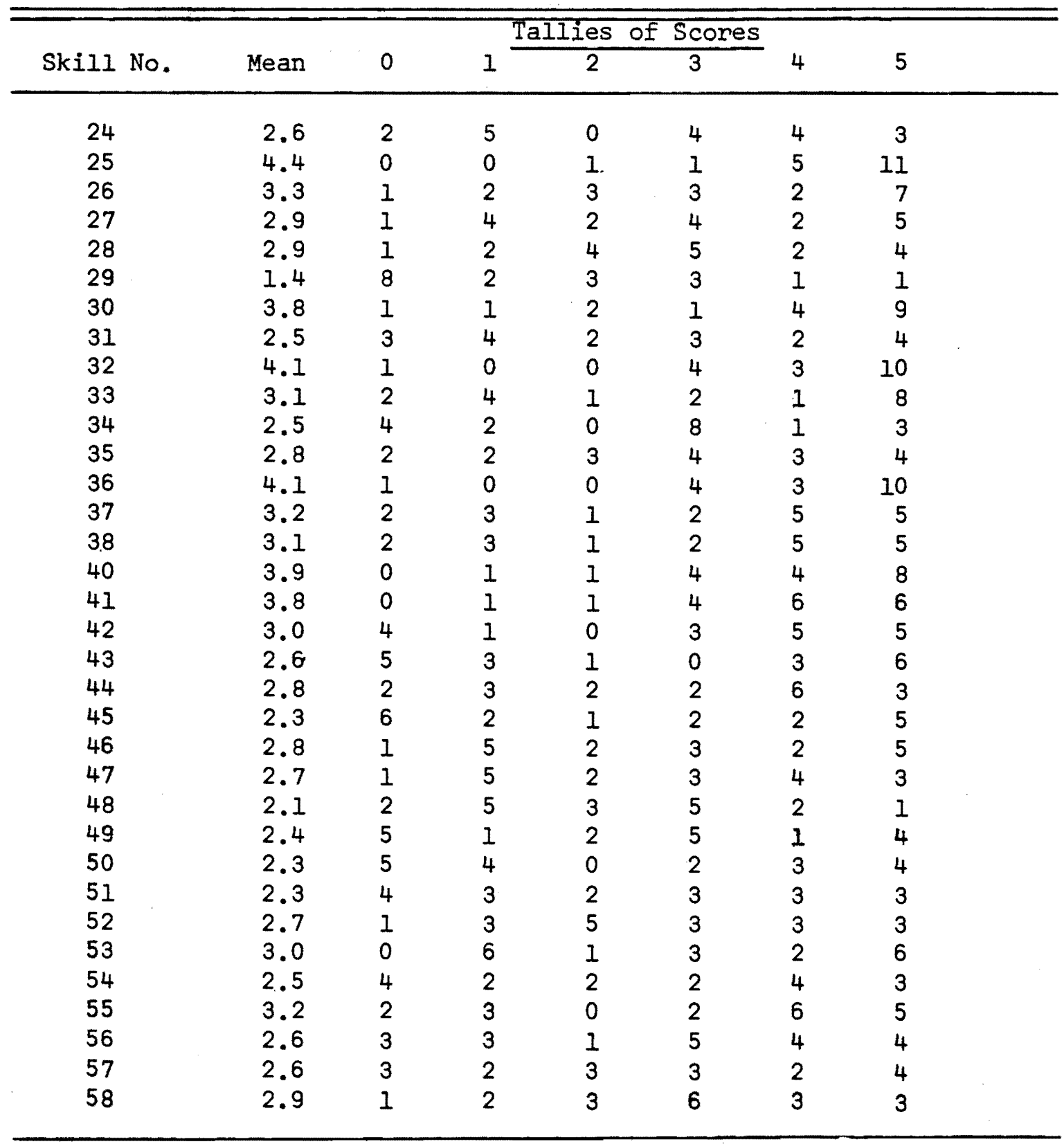


TABLE 11

DIRECT SERVICE SAMPLE GROUP MEANS AND VARIANCE AROUND THE MEANS

\begin{tabular}{|c|c|c|c|c|c|c|c|}
\hline Skill No. & Mean & 0 & 1 & $\frac{\text { ies }}{2}$ & $\frac{\text { of Scores }}{3}$ & 4 & 5 \\
\hline 24 & 2.4 & 2 & 4 & 3 & 6 & 4 & 1 \\
\hline 25 & 3.7 & 1 & 0 & 1 & 5 & $8^{\circ}$ & 5 \\
\hline 26 & 2.0 & 4 & 4 & 2 & 5 & 4 & 0 \\
\hline 27 & 2.7 & 1 & 3 & 4 & 7 & 3 & 2 \\
\hline 28 & 2.6 & 1 & 4 & 4 & 4 & 4 & 2 \\
\hline 29 & .75 & 11 & 6 & 0 & 3 & 0 & 0 \\
\hline 30 & 3.1 & 2 & 2 & 1 & 5 & 6 & 4 \\
\hline 31 & 2.0 & 3 & 6 & 3 & 5 & 1 & 2 \\
\hline 32 & 3.5 & 1 & 0 & 3 & 4 & $\overline{7}$ & 5 \\
\hline 33 & 1.6 & 7 & 4 & 3 & 4 & 0 & 2 \\
\hline 34 & 1.2 & 10 & 4 & 2 & 1 & 1 & 2 \\
\hline 35 & 2.2 & 1 & 6 & 5 & 5 & 2 & 1 \\
\hline 36 & 3.6 & 0 & 2 & 1 & 5 & 6 & 6 \\
\hline 37 & 2.7 & 2 & 8 & 0 & 0 & 4 & 6 \\
\hline 38 & 1.6 & 4 & 7 & 5 & 2 & 1 & 1 \\
\hline 39 & 3.3 & 2 & 1 & 1 & 3 & 10 & 3 \\
\hline 40 & 2.2 & 6 & 1 & 3 & 4 & 4 & 2 \\
\hline 41 & 2.4 & 3 & 2 & 5 & 6 & 2 & 2 \\
\hline 42 & 2.4 & 4 & 1 & 2 & 9 & 4 & 0 \\
\hline 43 & 1.7 & 8 & 2 & 3 & 2 & 4 & 1 \\
\hline 44 & 3.1 & 4 & 1 & 2 & 0 & 7 & 6 \\
\hline 45 & 1.8 & 8 & 1 & 4 & 1 & 5 & 1 \\
\hline 46 & 2.2 & 4 & 2 & 6 & 2 & 6 & 0 \\
\hline 47 & 2.2 & 4 & 2 & 5 & 4 & 4 & 1 \\
\hline 48 & 2.1 & 5 & 2 & 5 & 3 & 1 & 3 \\
\hline 49 & 2.3 & 4 & 3 & 2 & 6 & 3 & 2 \\
\hline 50 & 1.8 & 7 & 3 & 2 & 4 & 3 & 1 \\
\hline 51 & 2.4 & 4 & 5 & 0 & 4 & 4 & 3 \\
\hline 52 & 3.2 & 3 & 1 & 2 & 1 & 9 & 4 \\
\hline 53 & 2.3 & 4 & 3 & 3 & 4 & 4 & 2 \\
\hline 54 & 1.0 & 9 & 2 & 1 & 1 & 2 & 0 \\
\hline 55 & 3.1 & 3 & 1 & 2 & 5 & 3 & 6 \\
\hline 56 & 2.2 & 3 & 3 & 6 & 3 & 4 & 1 \\
\hline 57 & 2.2 & 6 & 2 & 2 & 4 & 4 & 2 \\
\hline 58 & 3.4 & 2 & 1 & 1 & 4 & 7 & 5 \\
\hline
\end{tabular}


JOILOVZd IO GAXL S.LNGGNOdSTY

NO बaSHG SWGLI TTIXS NO SNHaW anOYO JO JTgHL

H XIGNGddV 
TABLE 12

INFLUENCE OF EMPLOYMENT SETTING ON GROUP MEANS

\begin{tabular}{|c|c|c|c|c|c|c|c|c|}
\hline \multirow[b]{2}{*}{$\begin{array}{l}\text { skill } \\
\text { No. }\end{array}$} & \multicolumn{8}{|c|}{ Group Means of } \\
\hline & $\begin{array}{l}\text { CO } \\
\text { Sample }\end{array}$ & $\begin{array}{l}\text { NCO } \\
\text { Sample }\end{array}$ & $\begin{array}{l}\text { CO in } \\
\text { Adm./ } \\
\text { planning }\end{array}$ & $\begin{array}{l}\text { NCO in } \\
\text { Adm./ } \\
\text { planning }\end{array}$ & $\begin{array}{l}\text { Combined } \\
\text { Adm./ } \\
\text { planning }\end{array}$ & $\begin{array}{l}\text { CO in } \\
\text { direct } \\
\text { service }\end{array}$ & $\begin{array}{l}\text { NCO in } \\
\text { direct } \\
\text { service }\end{array}$ & $\begin{array}{l}\text { Combined } \\
\text { in direct } \\
\text { service } \\
\end{array}$ \\
\hline 24 & 2.6 & 2.4 & 2.8 & 2.5 & 2.7 & 2.0 & 2.6 & 2.5 \\
\hline 25 & 4.4 & 3.7 & 4.7 & 4.0 & 4.5 & 1.3 & 1.7 & 3.9 \\
\hline $2 \epsilon$ & 3.3 & 2.0 & 3.9 & 3.5 & 3.8 & 1.3 & 1.7 & 1.6 \\
\hline 27 & 2.9 & 2.7 & 3.4 & 3.0 & 2.8 & 1.5 & 2.8 & 2.5 \\
\hline 28 & 2.9 & 2.6 & 3.4 & 3.0 & 2.8 & 2.5 & 3.1 & 3.0 \\
\hline 29 & 1.4 & .75 & 1.4 & 1.3 & 1.4 & .5 & .7 & .7 \\
\hline 30 & 3.8 & 3.1 & 4.4 & 3.5 & 4.2 & 2.0 & 3.3 & 2.5 \\
\hline 31 & 2.5 & 2.0 & 2.9 & 1.5 & 2.6 & .8 & 2.3 & 2.0 \\
\hline 32 & 4.1 & 3.5 & 4.5 & 4.0 & 4.4 & 2.8 & 3.7 & 3.5 \\
\hline 33 & 3.1 & 1.6 & 3.7 & 2.5 & 3.4 & 1.0 & 1.5 & 1.4 \\
\hline 34 & 2.5 & 1.2 & 3.0 & 1.3 & 1.0 & .5 & 1.3 & 1.1 \\
\hline 35 & 2.8 & 2.2 & 3.3 & 2.3 & 3.1 & 1.5 & 2.3 & 2.1 \\
\hline 36 & 4.1 & 3.6 & 4.6 & 4.0 & 4.5 & 2.8 & 3.5 & 3.4 \\
\hline 37 & 3.2 & 2.7 & 3.4 & 3.5 & 2.9 & 2.5 & 2.4 & 2.4 \\
\hline 38 & 3.1 & 1.6 & 3.7 & 1.5 & 2.1 & 1.0 & 1.7 & 1.6 \\
\hline 39 & 4.0 & 3.3 & 4.4 & 3.3 & 4.2 & 2.8 & 3.5 & 3.4 \\
\hline 40 & 3.9 & 2.2 & 4.4 & 3.5 & 4.2 & 2.5 & 2.1 & 2.2 \\
\hline 41 & 3.8 & 2.4 & 4.3 & 2.8 & 4.0 & 2.5 & 2.5 & 2.5 \\
\hline 42 & 3.0 & 2.4 & 3.5 & 3.3 & 3.5 & .8 & 2.1 & 1.8 \\
\hline 43 & 2.6 & 1.7 & 3.2 & 3.3 & 3.2 & .3 & 1.5 & 1.3 \\
\hline 44 & 2.8 & 3.1 & 3.4 & 5.0 & 3.8 & 1.5 & 2.9 & 2.6 \\
\hline 45 & 2.3 & 1.8 & 2.9 & 3.5 & 3.0 & .3 & 1.5 & 1.3 \\
\hline 46 & 2.8 & 2.2 & 3.4 & 3.0 & 3.3 & .8 & 2.1 & 1.8 \\
\hline 47 & 2.7 & 2.2 & 3.2 & 2.8 & 3.1 & 1.3 & 2.3 & 2.1 \\
\hline 48 & 2.1 & 2.1 & 2.4 & .8 & 2.1 & 1.3 & 2.4 & 2.2 \\
\hline 49 & 2.4 & 2.3 & 2.8 & 2.8 & 2.8 & 1.3 & 2.4 & 2.2 \\
\hline 50 & 2.3 & 1.8 & 2.8 & 2.5 & 2.8 & .5 & 1.7 & 1.4 \\
\hline 51 & 2.3 & 2.4 & 2.8 & 3.3 & 2.9 & 1.0 & 2.2 & 1.9 \\
\hline 52 & 2.7 & 3.2 & 3.0 & 4.5 & 3.3 & 3.3 & 2.9 & 3.0 \\
\hline 53 & 3.0 & 2.3 & 3.4 & 4.3 & 3.6 & 1.3 & 2.0 & 1.9 \\
\hline 54 & 2.5 & 1.0 & 2.7 & .8 & 2.3 & .8 & .8 & .8 \\
\hline 55 & 3.2 & 3.1 & 3.9 & 4.3 & 4.0 & 1.0 & 3.0 & 2.6 \\
\hline 56 & 2.6 & 2.2 & 3.3 & 2.5 & 3.1 & .8 & 2.3 & 2.0 \\
\hline 57 & 2.6 & 2.2 & 3.1 & 2.0 & 2.9 & .5 & 2.4 & 2.0 \\
\hline 58 & 2.9 & 3.4 & 3.3 & 3.3 & 3.3 & 1.8 & 3.5 & 3.1 \\
\hline
\end{tabular}




\section{SELECTED BIBLIOGRAPHY}

Berg, Ivar. Education and Jobs: The Great Training Robbery. New York: Praeger Publishers, 1970.

Boehm, Werner, gen. ed. Council on Social Work Education Curriculum Study 12 vols. New York: Council on Social Work Education, 1959. Vol. 1: Objectives of the Social Work Curriculum of the Future, by Werner Boehm, ed.

, gen. ed. Council on Social Work Education Curriculum Study 12 vols. New York: Council on Social Work Education, 1959. Vol. 4: The Community Organization Method in Social Work Education, by Harry L. Lurie, ed.

Burns, Eveline. "Tomorrow's Social Work Needs and Social Work Education." Journal for Social Work Education 2 (Spring 1966): 10-20.

Columbia University School of Social Work. "Skills of à Community Organizer." New York: Columbia University Press, n.d. (Mimeographed.)

Council on Social Work Education. "Contemporary Education for Social Work in the United States." Jounnal of the Council on Social Work Education (Fall 1966): 20-23.

Cox, Fred M.; Erlich, John L.; Rothman, Jack; Tropman, John E., eds. Strategies of Community Organization. Itasca, Ill.: F. E. Peacock Publishers, 1970 .

David, Henry. "Education for the Professions: Common Issues, Problems and Prospects." Journal of Education for Social Work 3 (Spring 1967): 8-9.

DeCristoforo, Richard; Freidmund, Justus; Hahn, Lewis; Hansen, Herbert; Henifen, Arne; Kalogeratos, June; Kim, Hyung; Peterson, Richard; Smith, Louise; Wirchester, Lewis. "Development of a Tool to Measure Applicability of General Systems Theory to Generic Social Work." M.S.W. Thesis, Portland State University School of Social Work, June 1965.

Educational Coordinating Council, State of Oregon. "Recommendations for Human Service Training." Salem, Oregon: December 1972. (Mimeographed.)

Etzioni, Amitai. Readings on Modem Organizations, Prentice-Hall Readings in Modern Sociology Series. Englewood Cliffs, N.J.: 
Prentice-Hall, 1969.

Frey, Gerald A. Memorandum on the School of Social Work Social Welfare Planning Option, 22 May 1973. (Mimeographed.)

Friedlander, William. "Community Action for Public Welfare." Supplement no. 4 Challenge to Validity. Chicago: American Public Welfare Association, April 1968.

Gurin, Arnold. Community Organization Curriculum in Graduate Social Work Education. New York: Council on Social Work Education, 1970.

. "Role of the Social Worker in Social Planning." in Issues in Social Planning. N.p.: n.d., pp. 20-29. (Mimeographed.)

Hall, Richard H. Organizations: Structure and Process. Englewood Cliffs, N.J.: Prentice-Hall, 1972.

Harper, Ernest and Dunham, Arthur, eds. Community Organization in Action. New York: Association Press, 1970.

Hearn, Gordon. Memorandum on the School of Social Work Curriculum Policy Committee Proposal, 10 April 1973. (Mimeographed.)

Johns, Ray. Executive Responsibility in Volunteer Community Social Welfare Organizations. New York: Association Press, 1954.

Hahn, Alfred J. Studies in Social Policy and Planning. New York: Russell Sage Foundation, 1969.

- Theory and Practice of Social Planning. New York: Russell Sage Foundation, 1969 .

- Social Policy and Social Services. New York: Random House, 1973.

Haplan, Jerome. "Mobilizing Community Resources." Chicago: American Public Welfare Association, February 1955.

Kramer, Ralph and Specht, Harry, eds. Readings in Community Organization. Englewood Cliffs, N. J.: Prentice-Hali, 1969.

Lippit, Ronald; Watson, Jeanne; and Westley, Bruce. The Dynamics of Planned Change. New York: Harcourt, Brace and World, 1958.

Lowy, Louis; Bloksberg, Leonard; and Walberg, Herbert. Integrative Learning and Teaching in Schools of Social Work. New York: Association Press, 1971.

Morris, Robert and Binstock, Robert. Feasible Planning for Social Change. New York: Columbia University Press, 1966. 
National Association of Social Workers. Report of the Pre-Conference of the International Conference of Social Work. Boston: National Association of Social Workers, 22 April 1964.

Pederson, Lora Lee, ed. "Regional Planning for Social Work." Proceedings of the Vanderbilt Scarrilt College and Peabody College Conference. Nashville, Tenn.: n.p., 1948.

Phillips, Bernard S. Social Research: Strategy and Tactics. New York: Macmillan Co., 1966.

Portland State University School of Social Work. "The Social Welfare Planning Concentration." Draft of the chapter for the 1974 Reaccreditation Report, Portland, Ore.

- Minutes of the Social Welfare Planning Curriculum Committee, November 14, 1973 "Brainstorming" Session on Planning Skills. (Mimeographed.)

Ross, Murray G. Community Organization: Theory, Principles and Practice. New York: Harper \& Brothers, 1955.

Rothman, Jack. "Three Models of Community Organization Practice." In Strategies of Community Organization, pp. 20-37. Edited by Fred Cox et al. Itasca, Ill.: Peacock Publishers, 1970.

, ed. Promoting Social Justice in the Multigroup Society, with a Preface by Arnulf M. Pins. New York: Association Press, 1971.

and Jones, Wyatt. A New Look at Field Instruction. New York: Association Press, 1971.

Schwartz, Edward E., ed. Planning, Programming and Budgeting Systems and Social Welfare. Chicago: University of Chicago School of Social Service Administration, 1971.

Sexton, William P., ed. Organizational Theories. Columbus, Ohio: Charles Merrill Publishing Co., 1970.

Spencer-Chapin Adoption Services. The New Faces of Social Work. New York: Woodhaven Press, 1969.

Warren, Roland L. Truth, Love and Social Change, Rand McNally Sociology Series. Chicago: Rand McNally and Co., 1971.

Wessel, Rosa, ed. Journal of Social Work Process. Philadelphia: University of Pennsylvania Press, 1969. 